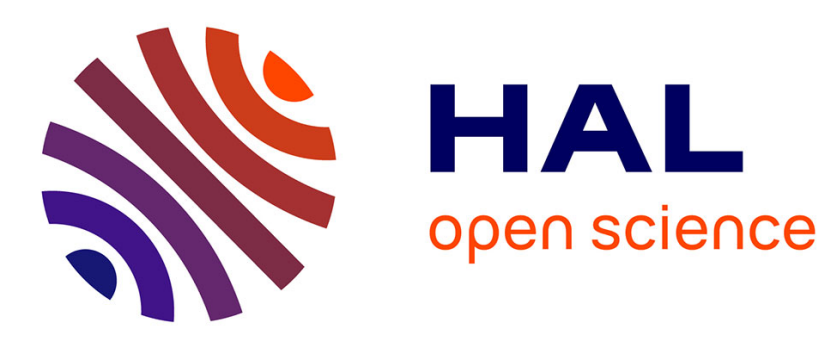

\title{
A Physiologically Based Toxicokinetic Model for the Zebrafish Danio rerio
}

Alexandre R.R. Pery, James Devillers, Céline Brochot, Enrico Mombelli, Olivier Palluel, Benjamin Piccini, François Brion, Rémy Beaudouin

\section{To cite this version:}

Alexandre R.R. Pery, James Devillers, Céline Brochot, Enrico Mombelli, Olivier Palluel, et al.. A Physiologically Based Toxicokinetic Model for the Zebrafish Danio rerio. Environmental Science and Technology, 2014, 48 (1), pp.781-790. 10.1021/es404301q . ineris-01710151

HAL Id: ineris-01710151

https://hal-ineris.archives-ouvertes.fr/ineris-01710151

Submitted on 15 Feb 2018

HAL is a multi-disciplinary open access archive for the deposit and dissemination of scientific research documents, whether they are published or not. The documents may come from teaching and research institutions in France or abroad, or from public or private research centers.
L'archive ouverte pluridisciplinaire HAL, est destinée au dépôt et à la diffusion de documents scientifiques de niveau recherche, publiés ou non, émanant des établissements d'enseignement et de recherche français ou étrangers, des laboratoires publics ou privés. 


\section{A physiologically-based toxicokinetic model for the zebrafish Danio rerio}

Alexandre R.R. Péry, ${ }^{\dagger *}$ James Devillers, ${ }^{\ddagger}$ Céline Brochot, ${ }^{\dagger}$ Enrico Mombelli, ${ }^{\dagger}$ Olivier Palluel, ${ }^{\S}$ Benjamin Piccini, ${ }^{\S}$ François Brion, ${ }^{\S}$ and Rémy Beaudouin ${ }^{\dagger}$

Unité Modèles pour l'Écotoxicologie et la Toxicologie (METO), INERIS, Parc Technologique Alata, BP2, 60550 Verneuil-en-Halatte, France, CTIS, 3 Chemin de la gravière, 69140 Rillieux La Pape, France and Unité Ecotoxicologie in vitro et in vivo (ECOT), INERIS, Parc Technologique Alata, BP2, 60550 Verneuil-en-Halatte, France

\footnotetext{
${ }^{\dagger}$ METO

$\$$ CTIS

${ }^{\S}$ ECOT
}

*Corresponding author phone: +33 3445561 26; fax: +33 3445567 67; e-mail: alexandre.pery@ineris.fr 


\begin{abstract}
Zebrafish (Danio rerio) is a widely used model for toxicological studies, in particular those related to investigations on endocrine disruption. The development and regulatory use of in vivo and in vitro tests based on this species can be enhanced by toxicokinetic modeling. For this reason, we propose a physiologically based toxicokinetic (PBTK) model for zebrafish describing the uptake and disposition of organic chemicals. The model is based on literature data on zebrafish, other cyprinidae and other fish families, new experimental physiological information (volumes, lipids and water contents) obtained from zebrafish, and chemicalspecific parameters predicted by generic models. The relevance of available models predicting the latter parameters was evaluated with respect to gill uptake and partition coefficients in zebrafish. This evaluation benefited from the fact that the influence of confounding factors such as body weight and temperature on ventilation rate was included in our model. The predictions for six chemicals (65 data points) yielded by our PBTK model were compared to available toxicokinetics data for zebrafish and all of them were within a factor of 5 of the corresponding experimental values. Sensitivity analysis highlighted that the 1-octanol/water partition coefficient, the metabolism rate, and all the parameters that enable the prediction of assimilation efficiency and partitioning of chemicals need to be precisely determined in order to allow an effective toxicokinetic modeling.
\end{abstract}




\section{INTRODUCTION}

Zebrafish (Danio rerio) is now used worldwide in a variety of biological disciplines ranging from basic developmental biology to applied toxicology ${ }^{1}$. In the last few years, zebrafish studies on Endocrine Disrupting Chemicals (EDCs) led to significant advances to assess mode of action of EDCs on steroid receptor-regulated pathways ${ }^{2-4}$, through both in vitro and in vivo reported gene models ${ }^{3,5}$ or in vivo assays recognized at international level ${ }^{6,7}$. Zebrafish has been found useful in EDC investigation ${ }^{8}$ and has, by far, been the most widely used fish species for endocrine studies in the past five years ${ }^{9}$.

To fully exploit the potential of zebrafish in vitro and in vivo tests, it is necessary to deploy a tool to relate local toxicokinetics (at cell, organ and endocrine system levels) and exposure at whole body level. A specific class of toxicokinetic models, the physiologically based toxicokinetic or pharmacokinetic models - PBTK or PBPK- is adequate for this by coupling kinetics at local level (cell or organ) and global kinetics at whole body level ${ }^{10}$. A PBTK model consists of a series of mathematical equations, based on the specific physiology of an organism and on the physicochemical properties of a substance, which are able to describe the absorption, distribution, metabolism and excretion (ADME) of the compound within this organism. PBPK models present many other advantages. First, the possibility to calibrate them based only on in vitro and computing data permits to replace, or at least reduce, the needs for animal testing ${ }^{10,11}$. Second, they can constitute the basis for computational models able to describe the perturbation of endocrine systems ${ }^{12,13}$. Third, as shown by Stadnicka et al. ${ }^{11}$, multi-compartment models, such as PBPK models, generally outperform simple one compartment models with respect to simulating chemical concentrations in fish whole body.

The reference for fish PBPK models is still the pioneer works by Nichols et al. ${ }^{14}$, who developed a model for the rainbow trout (Oncorhyncus mykiss). Twenty years later, the 
estimates of physiological parameters by Nichols et al. are still the basis of following PBPK models developed for fish ${ }^{11-13,15}$. At present, no PBPK model has ever been developed for fish as small as zebrafish, for which there is still rather fragmentary knowledge of basic biological traits.

We propose a PBPK model for zebrafish adults exposed in standard conditions to non-ionic organic chemicals in water. To achieve this, new dedicated physiological information (volumes, lipid and water contents) was obtained experimentally with zebrafish, and generic models to predict chemical-specific parameters were evaluated in regard to their relevance to predict kinetics in zebrafish. Finally, the predictions of our PBPK model were compared for many chemicals to available toxicokinetics data for zebrafish.

\section{MATERIALS AND METHODS}

\section{Model structure and equations}

Our PBPK model is presented in Figure 1, and the equations are provided in Supporting Information, S1. The model comprises eight compartments: gills, arterial and venous blood, liver, gonads, brain, poorly perfused tissues and richly perfused tissues. Inclusion of liver, gonads and brain will permit later to address perturbations of the hypothalamic-pituitarygonadal axis as performed for other fish species ${ }^{12,13}$. As in Nichols et al. ${ }^{14}$, venous blood out of richly perfused tissues and gonads join the portal vein and enter the liver. We performed a visual inspection of Danio rerio fish blood circulation in organisms from our laboratory culture and found veins from gonads to liver, confirming this approach. Uptake and elimination are considered to occur through the gill, with no substantial accumulation in this compartment. Uptake rate is proportional to volumetric flow rate of water and assimilation efficiency. Excretion rate is proportional to the same parameters and inversely proportional to 
the partition coefficient of the substance between blood and water. Biotransformation in the liver is considered.

\section{Physiological parameter calibration}

The values of the physiological parameters for Danio rerio adult males and females are provided in Table 1. Gonad, liver, brain and carcass were dissected, weighed for fresh tissue masses and subsequently lyophilized for 2 days (PowerDry PL3000, Thermo Scientific). Wet and dried weight for brain, liver, gonads and carcass were measured in 10 adult males (with total wet weight ranging from 497 to $769 \mathrm{mg}$ ) and 10 adult females (with total wet weight ranging from 734 to $1695 \mathrm{mg}$ ). The data are reported in Supporting Information, S2. Additional measurements (for blood, richly perfused tissues and gonads) were kindly provided by colleagues from IRSN (Institut de Radioprotection et de Sureté Nucléaire). Despite an extensive bibliographic research, we could not find data for fish arterial blood volume. We assumed that this volume is one third of the total blood volume, as in mammals. For female gonads, we compiled data provided by INERIS and IRSN colleagues and the data published by Örn et al. ${ }^{16}$ (See Supporting Information, S3), and decided to distinguish between low weight females (weight below $500 \mathrm{mg}$ ), with a mean percentage of gonads in total weight of $8 \%$, and high weight females with a mean percentage of gonads in total weight of $17 \%$.

The only available data for cyprinids relative to volumetric flow rate of water through the gills, $F W_{\text {gil }}(\mathrm{ml} / \mathrm{min})$, are related to carps. Yamamoto ${ }^{17}$ derived a relationship for ventilation volume and weight at $25^{\circ} \mathrm{C}$ in normoxic conditions, $\mathrm{V}_{\mathrm{g}}=1.035226 B W^{0.771371}$. Usually, a multiplicative corrective factor for temperature is proposed with an exponential dependence on temperature ${ }^{18}$. We thus added a corrective factor for temperature extrapolation, $\mathrm{e}^{0.04 T}$, estimated from a regression of the data on the temperature-dependency of oxygen uptake rate 
in Danio rerio from Vergauwen et al. ${ }^{19}$. The ventilation rate estimate we thus obtained for a $0.4 \mathrm{~g}$ cyprinid at $27^{\circ} \mathrm{C}$ would be $0.55 \mathrm{ml} / \mathrm{min}$.

We calculated the cardiac output based on the number of beats per minute in adult zebrafish at $26^{\circ} \mathrm{C}$ estimated at $111^{20}$ and on the ratio between stroke volume and weight for trouts, estimated at $0.2 \mathrm{~mL} / \mathrm{kg}^{21}$. An adult zebrafish weighting $500 \mathrm{mg}$ would then have a stroke volume of $0.1 \mu \mathrm{L}$, and a cardiac output of $11.1 \mu \mathrm{L} / \mathrm{min}$ or $0.666 \mathrm{~mL} / \mathrm{h}$. The same correction for temperature as for volumetric flow rate through the gills was used to adapt cardiac output to given experimental conditions.

Other physiological parameters, the water and lipid contents per organ of interest, have to be provided for the prediction of chemical-specific parameters. The water content was deduced from the ratio of dry to wet weights. The lipid content was measured using a colorimetric sulfo-phospho-vanillin (SPV) assay $^{22}$ performed in 96-well microplate after total lipid extractions on lyophilized tissues performed as described by Lu et al. ${ }^{23}$.

The total lipid content was adjusted to $5 \%$ of bodyweight, which is the average lipid content of the small fish used in OECD TG 305 on fish bioconcentration assessment ${ }^{24}$.

\section{Substances-specific parameter calibration}

For the logarithm of assimilation efficiency, Barber ${ }^{18}$ deduced an equation from the data by Thomann et al. ${ }^{25}$ as a function of the logarithm of the 1-octanol/water partition coefficient, $\log K_{\text {ow }}: 0.577 \log K_{o w}-2.81$ for $\log K_{\text {ow }}<4.7, \log 0.8$ for $\log K_{\text {ow }}$ values between 4.7 and 6.75 and $-0.731 \log K_{o w}+4.84$ for higher $\log K_{o w}$ values. We checked the relevance of this equation for Danio rerio by comparing its prediction to those deduced from available uptake rates in the literature. Each of these uptake rates is indeed equal to assimilation efficiency multiplied by the volumetric flow rate of water through the gills. For the comparison, the volumetric 
flow rates were scaled to fish body weight and temperature of the study as explained in the physiological calibration section. We used data on tetrachlorobenzyltoluene (TCBT) ${ }^{26}$, three $\mathrm{PCBs}^{27}$, pentachlorophenol ${ }^{28}$, hexachlorocyclohexane ${ }^{29}$, endosulfan $^{30}$, ethinylestradiol ${ }^{31}$, tebuconazole $^{32}$, diazinon ${ }^{33}$ with $\log K_{\text {ow }}$ from 3.7 to 7.8 . We added additional data for carp exposed to three chloroanilines ${ }^{34}$ to provide information for lower $\log K_{o w}$ (1.81-1.88).

For the partition coefficient $\lambda_{b w}$ between blood and water, we propose the following regression equation, derived from the data by Bertelsen et al. ${ }^{35}$, Fitzsimmons et al. $^{36}$ and Escher et al. ${ }^{37}$ on Oncorhynchus mykiss:

We chose to focus on the fish species for which the highest amount of in vivo data, produced in comparable experimental conditions, was available. We used recommended experimental $\log K_{\text {ow }}$ values from Sangster ${ }^{38}$ for PCBs and Hansch et al. ${ }^{39}$ for the other compounds.

For the tissue to blood partition coefficients, two equations were used. Bertelsen et al. ${ }^{35}$ proposed a simple generic model to predict partition coefficients between tissues and water for four species (catfish, medaka, fathead minnow, trout):

This equation was based on data for 6 chemicals with $\log K_{o w}$ values ranging from 1.46 to 4.04. We propose to evaluate the relevance of another model, as proposed by Nichols et al. ${ }^{40}$, updated for non-lipid content coefficient $(0.05 \text { instead of } 0.035)^{41}$ : 
We compared the outcomes of the PBPK models corresponding to these two models, in terms of bioconcentration factors, to available data in the literature ${ }^{25-32,42}$ for D. rerio.

When available, in vitro metabolism data were used to calibrate liver metabolism in the PBPK model. The scaling factors proposed by Nichols et al. ${ }^{40}$ for rainbow trout were used. The mean values were $37.8 \mathrm{mg}$ microsomal protein/g liver, $135 \mathrm{mg} \mathrm{S} 9$ proteins/g liver and 216.6 and $234.8 \mathrm{pmol} \mathrm{CYP} / \mathrm{mg}$ microsomal protein respectively for male and female, the two latter values corresponding to the sum of the only three CYP contents $(2 \mathrm{M} 1,2 \mathrm{~K} 1,3 \mathrm{~A} 27)$ indicated in the paper by Nichols et al. Thus the value we use to scale CYP contents may underestimate actual metabolism rate. To compare, the total CYP content in humans and rats is respectively 300-600 and 800-1100 pmol CYP/mg microsomal protein ${ }^{43}$.

\section{Experimental toxicokinetics data}

Table 2 presents the studies that we used to compare our predictions to observed toxicokinetic data. All these studies were performed with Danio rerio and utilized several time points of measurement of internal concentrations, permitting assessment of the relevance of the predictions not only for bioconcentration factors but also for uptake and elimination rates. For some compounds, a depuration period followed exposure. For most of the studies, fish of both sexes were used with no information on sex ratio. We thus calculated the kinetics predictions for males and females, assuming same weight (the one indicated in the study publication) for both sexes. In case the information for weight was also missing, we used a default value of $0.4 \mathrm{~g}$, which is the median value of the studies we considered. Supporting Information, S4, provides metabolism data, which were not available for all substances. For diazinon, we had data obtained with zebrafish homogenates $\mathrm{S} 13^{44}$. For endosulfan (alpha and beta) and tebuconazole, only data for mammals (rat microsomes for tebuconazole, human ones for the two stereoisomers of endosulfan) were available ${ }^{45-46}$. For bisphenol $\mathrm{A}$, as this compound is 
generally extensively metabolized ${ }^{47}$, we assumed that bisphenol A metabolism was only limited by liver blood flow. When measured exposure concentration data were available, we used them instead of nominal values. Tebuconazole exposure concentration was provided through a time-dependent equation ${ }^{32}$. For ethinyl-estradiol, we also had to account for the disappearance of the substance in the exposure solution due to accumulation in the fish (and the appearance of the substance in the exposure solution during depuration). The kinetics of exposure concentration was thus included in the model (See Supporting Information, S1).

\section{Sensitivity analysis}

The sensitivity analysis orders the inputs by importance, identifying the main contributors to the variation in the model outcome. Sensitivity analysis was performed using the variancebased Sobol method (Sobol et al. ${ }^{48}$; Saltelli et al. ${ }^{49}$ ). It is a global and model independent sensitivity analysis method that is based on variance decomposition (quantifying the amount of variance that each parameter contributes to the unconditional variance of the model output). It can handle non-linear and non-monotonic functions and models.

Model output variances were estimated using Monte Carlo integrals. Two independent input sample $n \times p$ matrices (the "sample" matrix M1 and the "resample" matrix M2), where $n$ is the sample size $(n=50,000)$ and $p$ the number of parameters $(p=31)$, were used to compute the Monte Carlo integrals. Every row in M1 and M2 represents a possible parameter combination for the model. The first order sensitivity index $(\mathrm{Si})$ is the variance contribution of one parameter $i$ to the total model variance. Total Sobol' sensitivity index (STi) is the result of the main effect of the parameter $i$ and of all its interactions with the other parameters (up to the pth order). 
First order and total Sobol' sensitivity indices were estimated for the total, liver, gonad, brain and rest of the body concentration at 1, 24, 48 and $72 \mathrm{~h}$, considering an experimental design with an accumulation phase from 0 to $48 \mathrm{~h}$, then an elimination (no exposure) phase from 48 to $72 \mathrm{~h}$. Two sensitivity analyses were performed, one considering all parameters, and one considering only the parameters that would be specific of a given experimental study for a given chemical, with the QSAR predictions inside the PBPK model, for partition coefficients and assimilation efficiency, fixed. More details are available in Supporting Information, S8.

To assess confidence intervals on the estimation of Sobol' Indices, bootstrapping with resampling was used. The $n$ samples used for the model evaluations were 1,000 times sampled with replacement, whereby for each resampling the SI was calculated. In this way, distributions for the Si and STi values were obtained and the $95 \%$ confidence intervals were built $^{50}$.

Sensitivity analysis was performed under the $\mathrm{R}$ Cran environment using the function «sobol2007» implemented in the package «sensitivity $»^{51}$.

\section{RESULTS AND DISCUSSION}

\section{Substances-specific parameter calibration}

Figure 2 shows the comparison between measured data (corrected for weight and temperature) for assimilation efficiency and the equation in the Barber paper ${ }^{18}$. It appears that this equation provides an acceptable prediction of the relationship between $\log K_{o w}$ and assimilation efficiency. The ratio between predicted and measured values ranged from 0.1 to 3 in our data set, with a mean value of 1.3. This variability could be due to the fact that metabolism is not accounted for in the calculation of assimilation efficiency based on uptake rates. A high metabolism rate can induce a low apparent assimilation efficiency, because most 
of the substance entering the body would be eliminated at a rate comparable to the uptake one. For tebuconazole, if no metabolism occurred, the measured assimilation efficiency based on the experiment by Andreu-Sanchez et al. ${ }^{32}$, would be 5 to 10 times higher than what these authors measured. This would explain the differences of a factor 12 between measured and predicted values for this substance. In Supporting Information, S5, we illustrate the importance of correcting for weight and temperature, by showing a substantial loss of accuracy of the predictions when no correction is performed. The PBPK models available for fish, even when authors realize some discrepancy between the parameters they use, estimated at cold temperature, and their need for a species exposed in warm situation (for instance using trout parameters to calibrate a fathead minnow model), usually do not account mathematically for this ${ }^{52}$. Temperature can however introduce a substantial bias (for instance a factor of 1.5 for a difference of $\left.10^{\circ} \mathrm{C}\right)$.

Concerning the prediction of the blood:water partition coefficient, we compared the outcomes of our equation to measured data and to another equation proposed by $\operatorname{Barber}^{18}$ :

Table 3 provides the predictions and measured values. In general Equation 1 provides better and more robust estimates than Equation 4 in the range of $K_{o w}$ values that we considered. This is not so surprising because Equation 1 has been derived from a larger and more structurally diverse dataset than Equation 4. The experimental values for the substances 7 to 10 were obtained on the same species by Fitzsimmons et al. ${ }^{36}$, with up to one order of magnitude of variability in the measurements for the same substance. This gives an idea of the maximal accuracy that we could hope to reach with the models. 
Figure 3 shows the comparison between measured whole body bioconcentration factors and those predicted with PBPK models calibrated based on the model by Bertelsen et al. (35) and the updated one by Nichols et al. ${ }^{40}$. For the BCF values below 300 (corresponding to $\log K_{\text {ow }}$ values below 4), the model by Bertelsen ${ }^{35}$ provided a better prediction than the one by Nichols ${ }^{40}$, for 14 out of 23 chemicals. Note that the model by Bertelsen is suited in its applicability domain ([1.46-4.04]). In contrast, for chemicals with $\log K_{o w}$ values exceeding 4, the Bertelsen model under-predicts accumulation, whereas the Nichols one performs better (for 10 out of 11 chemicals). We thus suggest to consider these two models for the prediction of tissue:water partition coefficients for chemicals with a $\log K_{o w}$ value below 4 , only the Nichols one for those with a $\log K_{o w}$ value above 4 .

Other approaches perform better to link $K_{\text {ow }}$ value and whole body bioconcentration. Bintein et al $^{53}$ provided a bilinear model which outperformed any linear and parabolic models, in particular for very hydrophobic compounds (The distribution of the residuals both on the training and external test sets was better, with no chemical considered as outlier). Figure S6, Supporting Information, provides the extension of Figure 3 with the model by Bintein et al. The regression proposed is more robust than PBPK predictions based on Equations 2 and 3 to predict BCF from low to high values of $K_{o w}$ (no underprediction for high $K_{o w}$ values, and better prediction than with Equation 3 for low $K_{\text {ow }}$ values). However, it does not permit to estimate tissue-specific parameters.

\section{Comparison between model predictions and experimental toxicokinetics data}

Figure 4 provides the comparison between the toxicokinetics predicted by the model and the measured data for the 6 substances. In general, the predictions are close to the experimental values (there is, at worst, a factor of 3 between measured values and those predicted by the model or by the closest one when using a model without metabolism or with metabolism 
parameters extrapolated from mammals). The quality of the predictions is thus comparable to other ones obtained with fish PBPK models calibrated with in vitro or in vivo data ${ }^{14-15}$. In particular, our model performance is comparable to the ones by Stadnicka et al. ${ }^{11}$, in terms of quality of the predictions for the 6 chemicals we studied. Stadnicka et al. ${ }^{11}$ evaluated a higher number of chemicals with a similar number of data points ( 23 chemicals for rainbow trout and 39 data points, 24 for fathead minnows and 68 data points). For their PBPK model, $77 \%$ of the predictions for rainbow trout and $80 \%$ for fathead minnow were within a factor of 5 compared to the measured values, and the coefficient of determination $\left(R^{2}\right)$ were respectively 0.78 and 0.73 for these two species. In our study, we found, for 65 data points, a coefficient of determination of 0.83 , and $88 \%$ of the predictions within a factor of 5 compared to the measured values (Supporting Information, S7), the bad predictions corresponding to the predictions of the elimination data for endosulfan.

For ethinyl estradiol (EE2), we also dispose of bioconcentration values for different compartments $^{31}$ : our model would largely underestimate the value for liver (measured: 19,255; predicted: 1,660). Blewett et al. ${ }^{54}$ also found a high accumulation of EE2 in fish liver and gallbladder (with half of the substance found in these organs). This suggests that the accumulation of EE2 in the liver is not only driven by water and lipid contents. Our model provides comparable values to the measured ones for the other organs/fluids (blood: measured 143; predicted: 261; gonads: measured 1,764; predicted: 3,821; brain: measured 852 ; predicted: 1,179). The good prediction of the kinetics of EE2 suggests that uptake through the gills is not particularly enhanced by the presence of sex hormone-binding globulins (SHBG) as suggested by some authors, like Miguel-Queralt and Hammond ${ }^{55}$. For instance, they observed a difference in uptake rates between cortisol (very low uptake rate) and EE2 and concluded that this could be linked to differences of affinity to SHBG. However, this could also be due to the difference between the $\log K_{o w}$ values (cortisol $=1.49-1.61$ vs. EE2 $=4.15$ ) 
resulting in a much lower assimilation efficiency and a much lower bioconcentration factor. The fact that fish hypothermic anaesthesia reduced drastically EE2 uptake rate in their experimental study could also be just due to a reduced ventilation rate. A strong linear correlation between EE2 uptake rate and the rate of oxygen consumption has been shown in fish $^{54}$, which supports our hypothesis for uptake. Such explanation would however not be applied to testosterone, with a low $K_{o w}$ of 3.3 showing both a high uptake rate and a reduced uptake in the presence of SHBG ligands in the solution, in the experiment by Miguel-Queralt and Hammond.

When metabolism rates were extrapolated from mammals data (endosulfan and tebuconazole), we chose to present in Figure 4 the predictions both using these metabolism values and assuming no metabolism. It appears from our results that tebuconazole is likely to be highly metabolized with values similar to those measured with rat microcomes, whereas endosulfan (alpha and beta) should be metabolized at a lower rate in zebrafish than in human microsomes, especially endosulfan alpha. In human microsomes, metabolism of endosulfan alpha is likely to occur mainly through CYP2B6 and CYP3A, whereas for endosulfan beta, metabolism is likely to occur mainly through CYP3A $\mathrm{A}^{46}$. The difference between the accuracy of the model to predict kinetics in zebrafish may thus be linked to the homology between human CYP2B6 and its zebrafish equivalent. For bisphenol A, the assumption of very high metabolism in the liver seems to be relevant, as shown by Lindholst et al. ${ }^{56}$.

The differences between predictions for males and females are significant only when metabolism is high (See for instance the figure for BPA), due to the differences relative to liver total blood flow, which includes gonad blood flow, higher in females than in males. The other physiological differences have limited impact on the toxicokinetics at whole body level. However, substantial differences are expected at organ level. For instance, for hydrophobic 
compounds, 3 times higher accumulation in the male gonads would be expected compared to the female ones, due to differences in lipid content.

\section{Sensitivity analysis}

Figure 5 presents the results of the sensitivity analysis, considering all the parameters in our model. The parameters, with, by far, the highest influence on the whole body concentrations are $\log K_{o w}$ and the parameters relative to partition coefficients and assimilation efficiency. The same holds to concentrations in the organs with $\log K_{\text {ow }}$ always one of the main influent parameters, and the assimilation efficiency parameters very influent in the first hours of accumulation. Metabolism rate is also very influent, especially relative to liver concentration. When fixing the parameters of the QSAR models (Supporting Information, S10), the most influent parameters are temperature, ventilation rate (especially for the absorption phase), so as metabolism, cardiac output and lipid content (especially for the elimination phase). This particularly enhances the relevance of the physiological measurements (lipid content in many organs) or extrapolations (cardiac outputs and ventilation rates as a function of temperature) proposed in the present study. The detailed outputs of the sensitivity analysis are available in Supporting Information, S9 and S11.

\section{Physiological relevance of the model}

The quality of the prediction of the kinetic data supports the relevance of our representation of the toxicokinetics in zebrafish. In the literature, some fish PBPK models do not account for the portal vein entering the liver. As they only consider hepatic artery flow from the model by Nichols et al. ${ }^{14}$, they substantially underestimate total blood flow through the liver (In

mammals, the ratio between portal vein and hepatic artery is around four ${ }^{57}$ ), and, consequently, liver metabolism rate. 


\section{ACKNOWLEDGMENTS}

This study was funded by the French Ministry in charge of Ecology and Sustainable Development, within the frameworks of the National Research Programme on Endocrine Disruption (PNRPE) and of the Programme 190. We would also like to thank the colleagues from IRSN (Institut de Radioprotection et de Sureté Nucléaire), Christelle Adam in particular, who provided physiological measures for Danio rerio. The authors are also very grateful to the three anonymous reviewers who greatly helped to improve the content and the clarity of this paper.

\section{ASSOCIATED CONTENT}

\section{Supporting Information}

Model details, data sources, and additional tables and figures. This information is available free of charge via the Internet at http://pubs.acs.org/ .

\section{REFERENCES}

Scholz S. The zebrafish has become an attractive model organism in many areas of research ranging from basic developmental biology to applied toxicology. Reprod. Toxicol. 2012, 33,127.

(2) Menuet, A.; Pellegrini, E.; Anglade, I; Blaise, O.; Laudet, V.; Kah, O.; Pakdel F. Molecular characterization of three estrogen receptor forms in zebrafish: binding characteristics, transactivation properties, and tissue distributions. Biol. Reprod. 2002, 66, 1881-92. 

Screening estrogenic activities of chemicals or mixtures in vivo using transgenic (cyp19a1b-GFP) zebrafish embryos. PLoS One 2012, 7, e36069.

(4) Vosges, M. ; Le Page, Y. ; Chung, B. C. ; Combarnous, Y. ; Porcher, J. M. ; Kah, O. Brion, F. 17 alpha-Ethinylestradiol disrupts the ontogeny of the forebrain GnRH system and the expression of brain aromatase during early development of zebrafish. Aquat. Toxicol. 2010, 99, 479-491. Cosnefroy, A.; Brion, F.; Maillot-Maréchal, E.; Porcher, J.M.; Pakdel, F.; Balaguer, P. Selective Activation of Zebrafish Estrogen Receptor Subtypes bya Zebrafish Liver Cell Line. Toxicol. Sci. 2012, 125, 439-449.

(6) Test No. 230: 21-day Fish Assay: A Short-Term Screening for Oestrogenic and Androgenic Activity, and Aromatase Inhibition; OECD Guidelines for the Testing of Chemicals, Section 2, OECD Publishing, 2009. doi: 10.1787/9789264076228$\underline{\text { en }}$

(7) Test No. 234: Fish Sexual Development Test; OECD Guidelines for the Testing of Chemicals, Section 2, OECD Publishing, 2011. doi: 10.1787/9789264122369-en, 2011.

(8) Segner, H. Zebrafish (Danio rerio) as a model organism for investigating endocrine disruption. Comp. Biochem. Physiol. C Toxicol. Pharmacol. 2009, 149, 187-195.

(9) Tokarz, J.; Möller, G., Hrabe de Angelis, M.; Adamski, J. Zebrafish and steroids: What do we know and what do we need to know? J. Steroid. Biochem. Mol. Biol. 2013, in press.

(10) Péry, A.R.R.; Brochot, C.; Zeman, F.A.; Mombelli, E.; Desmots, S.; Pavan, M.; Fioravanzo, E.; Zaldivar, J.M. Prediction of dose-hepatotoxic response in humans 
based on toxicokinetic/toxicodynamic modeling with or without in vivo data: A case study with acetaminophen. Tox. Lett. 2013, 220, 26-34.

(11) Stadnicka, J.; Schirmer, K.; Ashauer, R. Predicting concentrations of organic chemicals in fish by using toxicokinetic models. Environ. Sci. Technol. 2012, 46, 3273-3280.

(12) Watanabe, K.H.; Li, Z.; Kroll, K.J.; Villeneuve, D.L., Garcia-Reyero, N.; Orlando, E.F.; Sepulveda, M.S.; Collette, T.W.; Ekman, D.R.: Ankley, G.T.; Denslow, N.D. A computational model of the hypothalamic-pituitary-gonadal axis in male fathead minnows exposed to $17 \alpha$-ethinylestradiol and $17 \beta$-estradiol. Toxicol. Sci. 2009, 109, 180-192.

(13) Li, Z.; Kroll, K.J.; Jensen, K.M.; Villeneuve, D.L.; Ankley, G.T.; Brian, J.V.; Sepulveda, M.S.; Orlando, E.F.; Lazorchak, J.M.; Kostich, M.; Armstrong, B.; Denslow, N.D.; Watanabe, K.H. A computational model of the hypothalamicpituitary-gonadal axis in female fathead minnows (Pimephales promelas) exposed to $17 \alpha$-ethinylestradiol and 17ß-trenbolone. BMC Syst. Biol. 2011, 5, 63.

(14) Nichols, J.W.; McKim, J.M.; Andersen, M.E.; Gargas, M.L., Clewell III, H.J., Erickson, R.J. A physiologically based toxicokinetic model for the uptake and disposition of waterborne organic chemicals in fish. Toxicol. Appl. Pharmacol. 1990, $106,433-447$.

(15) Lien, G.J.; Nichols, J.W.; McKim, J.M.; Gallinat, C.A. Modeling the accumulation of three water borne chlorinated ethanes in fathead minnows (Pimephales promelas): a physiologically based approach. Environ. Toxicol. Chem. 1994, 13, 1195-1205. 

reproduction of an orally administered mixture of selected PCBs in zebrafish (Danio rerio). Arch. Environ. Contam. Toxicol. 1998, 35, 52-57.

Yamamoto, K. Relationship of respiration to body weight in the carp Cyprinus carpio under resting and normoxic conditions. Comp. Biochem. Physiol. 1991, $100 A, 113-116$.

(18) Barber, C.G. A review and comparison of models for predicting dynamic chemical bioconcentration in fish. Environ. Toxicol. Chem. 2003, 22, 1963-1992. Vergauwen, L.; Knapen, D.; Hanegaars, A.; De Boeck, G.; Blust, R. Assessing the impact of thermal acclimatation on physiological condition in the zebrafish model. Comp. Biochem. Physiol. B 1991, 183, 109-121.

(20) Warren, K.S.; Baker, K.; Fishman, M.C. The slow mo mutation reduces pacemaker current and heart rate in adult zebrafish. Am. J. Physiol. Heart Circ. Physiol. 2001, 281, H1711-H1719.

(21) McKim, J.M.; Lien, G.J.; Hoffman, A.D.; Jenson, C.T. Respiratory-cardiovascular physiology and xenobiotic gill flux in the lake trout (Salvelinus namaycush). Comp. Biochem. Physiol. Part A 1999, 123, 69-81.

(22) Cheng, Y. S.; Zheng, Y.; Van der Gheynst, J.S. Rapid Quantitative Analysis of Lipids Using a Colorimetric Method in a Microplate Format. Lipids 2011, 46, 95103.

(23) Lu, Y. H., Ludsin, S.A.; Fanslow, D.L.; Pthoven, S.A. Comparison of three microquantity techniques for measuring total lipids in fish. Can. J. Fish Aquat. Sci. 2008, 65, 2233-2241. 
Schlechtriem, C.; Fliedner, A.; Schäfers, C. Determination of lipid content in fish samples from bioaccumulation studies: contributions to the revision of guideline OECD 305. Environ. Sci. Europe 2012, 24, 13.

(25) Thomann, R.V.; Connoly, J.P.; Parkerton, T.F. An equilibrium model of organic chemical accumulation in aquatic food webs with sediment interaction. Environ. Toxicol. Chem. 1992, 11, 615-629.

(26) Bouraly, M.; Millischer, R.J. Bioaccumulation and elimination of tetrachlorobenzyltoluene (TCBT) by the rat and by the fish. Chemosphere 1989, $18,2051-2063$.

(27) Fox, K.; Zauke, G.-P.; Butte, W. Kinetics and bioconcentration and clearance of 28 polychlorinated biphenyl congeners in zebrafish (Brachydanio rerio). Ecotoxicol. Environ. Saf. 1994, 28, 99-109.

(28) Butte, W.; Willig, A.; Zauke, G.-P. Bioaccumualtion of phenols in zebrafish determined by a dynamic flow through test. In QSAR in Environmental Toxicology II; Kaiser, K.L.E., Ed.; D. Reidel Publishing Company: DordrechtBoston-Lancaster-Tokyo 1986; pp 43-53.

(29) Butte, W.; Fox, K.; Zauke, G.-P. Kinetics of bioaccumulation and clearance of isomeric hexachlorocyclohexanes. In QSAR in Environmental Toxicology IV; Hermens, J.L.M.; Opperhuizen, A., Eds.; Elsevier: Amsterdam-London-New York-Tokyo 1991; pp 377-382.

(30) Toledo, C.F.; Jonsson, C.M. Bioaccumulation and elimination of endosulfan in zebra fish (Brachydanio rerio). Pestic. Sci. 1992, 36, 207-211.

(31) Maes, H. Fate of ethinylestradiol in the aquatic environment and the associated effects on organisms at different trophic levels. Ph.D. Dissertation, Aachen University, Germany, 2011. 
Andreu-Sanchez, O.; Paraiba, L.C. ; Jonsson, C.M. ; Carrasco, J.M. Acute toxicity and bioconcentration of fungicide tebuconazole in zebrafish (Danio rerio). Environ. Toxicol. 2012, 27, 109-116.

Keizer, J.; D’Agostino, G.; Vittozzi, L. The importance of biotransformation in the toxicity of xenobiotics to fish. I. Toxicity and bioaccumulation of diazinon in guppy (Poecilia reticulata) and zebra fish (Brachydanio rerio). Aquat. Toxicol. 1991, 21, 239-254.

(34) Tsuda, T.; Aoki, S.; Kojima, M., Fujita, T. Accumulation and excretion of chloroanilines by carp. Chemosphere 1993, 26, 2301-2306.

Bertelsen, S.L.; Hoffman, A.D.; Gallinat, C.A.; Elonen, C.M.; Nichols, J.W. Evaluation of Log Kow and tissue lipid content as predictors of chemical partitioning to fish tissues. Environ. Toxicol. Chem. 1998, 17, 1447-1455.

(36) Fitzsimmons, P.N.; Fernandez, J.D.; Hoffman, A.D.; Butterworth, B.C.; Nichols, J.W. Branchial elimination of superhydrophobic organic compounds by rainbow trout (Oncorhynchus mykiss). Aquat. Toxicol. 2001, 55, 23-34.

(37) Escher, B.I.; Cowan-Ellsberry, C.E.; Dyer, S.; Embry, M.R.; Erhardt, S.; Halder, M.; Kwon, J.H.; Johanning, K.; Oosterwijk, M.T.T.; Rutishauser, S.; Segner, H.; Nichols, J. Protein and lipid binding parameters in rainbow trout (Oncorhynchus mykiss) blood and liver fractions to extrapolate from an in vitro metabolic degradation assay to in vivo bioaccumulation potential of hydrophobic organic chemicals. Chem. Res. Toxicol. 2011, 24, 1134-1143.

(38) Sangster, J. Octanol-Water Partition Coefficients: Fundamentals and Physical Chemistry; Wiley Series in Solution Chemistry: Wiley, Chichester, 1997.

(39) Hansch, C; Leo, A.; Hoekman, D. Exploring QSAR. Hydrophobic, Electronic, and Steric Constants; ACS Professional Reference Book: ACS Washington, 1995. 
Nichols, J.W.; Schultz, I.R.; Fitzsimmons, P.N. In vitro-in vivo extrapolation of quantitative hepatic biotransformation data for fish I. A review of methods, and strategies for incorporating intrinsic clearance estimates into chemical kinetic models. Aquat. Toxicol. 2006, 78, 74-90. deBruyn, A.M.; Gobas, F.A. The sorptive capacity of animal protein. Environ. Toxicol. Chem. 2007, 26, 1803-1808.

Kalsch, W.; Nagel, R.; Urich, K. Uptake, elimination and bioconcentration of ten anilines in zebrafish (Brachydanio rerio). Chemosphere 1991, 22, 351-363.

Cox Gad, S., Ed. Preclinical development handbook: ADME and biopharmaceutical properties; Wiley, 2008.

Fitzsimmons, P.N.; Lien, G.J.; Nichols, J.W. A compilation of in vitro rate and affinity values for xenobiotic biotransformation in fish, measured under physiological conditions. Comp. Biochem. Physiol. B 2007, 145, 485-506.

Shen, Z.; Zhu, W.; Liu, D.; Xu, X.; Zhang, P.; Zhou, Z. Stereoselective degradation of tebuconazole in rat liver microsomes. Chirality 2012, 24, 67-71. Lee, H.-K.; Moon, J.-K.; Chang, C.-H.; Choi, H.; Park, H.-W.; Park, B.-S.; Lee, H.-S.; Hwang, E.-C.; Lee, Y.-D.; Liu, K.-H.; Kim, J.-H. Stereoselective metabolism of endosulfan by human liver microsomes and human cytochrome P450 isoforms. Drug Metab. Dispos. 2006, 34, 1090-1095.

Hengstler, J.G.; Foth, H.; Gebel, T.; Kramer, P.-J., Lilienblum, W.; Schweinfurth, H.; Völkel, W.; Wollin, K.-M.; Gundert-Remy, U. Critical evaluation of key evidence on the human health hazrds of exposure to bisphenol A. Crit. Rev. Toxicol. 2011, 41, 263-291. 

the approximation errors when fixing unessential factors in global sensitivity analysis. Reliab. Eng. Syst. Saf. 2007, 92, 957-960. Saltelli, A.; Annoni, P.; Azzini, I.; Campolongo, F. ; Ratto, M. ; Tarantola, S. Variance based sensitivity analysis of model output. Design and estimator for the total sensitivity index. Comput. Phys. Commun. 2010, 181, 259-270.

(50) Nossent, J.; Elsen, P.; Bauwens, W. Sobol' sensitivity analysis of a complex environmental model. Environ. Model. Soft. 2011, 26, 1515-1525. $\mathrm{R}$ Core Team $R$ : A language and environment for statistical computing; $\mathrm{R}$ Foundation for Statistical Computing, Vienna, Austria, 2013.

Breen, M.; Villeneuve, D.L.; Ankley, G.T., Bncic,D.C.; Breen, M.S.; Watanabe, K.H.; Lloyd, A.L.; Conolly, R.B. Developing predictive approaches to characterize adaptative responses of the reproductive endocrine axis to aromatase inhibition: II. Computational modeling. Toxicol. Sci. 2013, 133, 234-247. Bintein, S.; Devillers, J.; Karcher, W. Nonlinear dependence of fish bioconcentration on n-octanol/water partition coefficient. SAR QSAR Environ. Res. 1993, 1, 29-39.

(54) Blewett, T.A.; Robertson, L.M.; MacLatchy, D.L.; Wood, C.M. Impact of environmental oxygen, exercice, salinity, and metabolic rate on the uptake and tissue-specific distribution of $17 \alpha$-ethinylestradiol in the euryhaline teleost Fundulus heteroclitus. Aquat. Toxicol. 2013, 138-139, 43-51.

(55) Miguel-Queralt, S.; Hammond, G.-L. Sex-hormone binding globulin in fish gills is a portal for sex steroids breached by xenobiotics. Endocrinology 2008, 149, 4269-4275. 
(56) Lindholst, C.; Wynne, P.M.; Marriott, P.; Pedersen, S.N.; Bjerregaard, P. Metabolism of bisphenol $\mathrm{A}$ in zebrafish (Danio rerio) and rainbow trout (Oncorhynchus mykiss) in relation to estrogenic response. Comp. Biochem. Physiol. C 2003, 135, 169-177.

(57) Davies, B.; Morris, T. Physiological parameters in laboratory animals and humans. Pharm. Res. 1993, 10, 1093-1096. 
Table 1. Physiological parameters values in the generic PBPK model.

\begin{tabular}{|c|c|c|c|}
\hline \multicolumn{2}{|l|}{ Parameter } & Value $(\mathrm{M} / \mathrm{F})^{\mathrm{a}}$ & Reference \\
\hline \multirow{5}{*}{$\begin{array}{l}\text { Percentage of total } \\
\text { Weight }(\%)\end{array}$} & Liver & $0.8 / 2.1$ & This study \\
\hline & Brain & $1.5 / 0.7$ & This study \\
\hline & Gonads & $1.8 / 8$ or 17 & This study \\
\hline & Blood & 1.6 & IRSN \\
\hline & Richly perfused & 5 & IRSN \\
\hline $\begin{array}{l}\text { Ventilation } \\
(\mathrm{ml} / \mathrm{min})\end{array}$ & $\left(0.4 \mathrm{~g} / 27^{\circ} \mathrm{C}\right)$ & 0.55 & $(18-20)$ \\
\hline $\begin{array}{l}\text { Cardiac output } \\
(\mu \mathrm{L} / \mathrm{min})\end{array}$ & $\left(0.5 \mathrm{~g} / 26^{\circ} \mathrm{C}\right)$ & 11.1 & This study \\
\hline \multirow{4}{*}{$\begin{array}{l}\text { Scaled blood flow } \\
\text { (only for males) }\end{array}$} & Liver & 0.02 & $(15)$ \\
\hline & Brain & 0.055 & (15) \\
\hline & Gonads & 0.066 & (15) \\
\hline & Richly perfused & 0.185 & (15) \\
\hline \multirow[t]{4}{*}{ Water content $(\%)$} & Liver & $65 / 69$ & This study \\
\hline & Brain & $75 / 76$ & This study \\
\hline & Gonads & $52 / 65$ & This study \\
\hline & Carcass & $68 / 65$ & This study \\
\hline \multirow[t]{4}{*}{ Lipid content (\%) } & Liver & $10.5 / 5.9$ & This study \\
\hline & Brain & $7.3 / 7.6$ & This study \\
\hline & Gonads & $22 / 7.6$ & This study \\
\hline & Rest of the body & $4.6 / 4.6$ & This study \\
\hline
\end{tabular}

\footnotetext{
${ }^{a}$ When differences between sexes exist, the values are presented as value for males/value for females.

${ }^{b}$ The organ blood flows were calculated as in Nichols et al. ${ }^{14}$, referring to the values for trout. The contribution of each blood flow to cardiac output was assumed to be proportional to the organ volume with a weighting factor (corresponding to perfusion rate) of 0.024 for the liver, 0.036 for the richly perfused tissues (including gonads and brain) and 0.007 for the poorly perfused tissues. We present the blood flow values calculated only for males, as, for females, these calculations depend on the volume of the gonads, which depends on female weight.
} 
Table 2. Characteristics of the experimental studies considered to compare model predictions and measured data.

\begin{tabular}{lllllll}
\hline Substance & $\begin{array}{l}\text { Weight } \\
(\mathrm{g})\end{array}$ & $\begin{array}{l}\text { Temperature } \\
\left({ }^{\circ} \mathrm{C}\right)\end{array}$ & Sex & $\begin{array}{l}\text { Number of } \\
\text { timepoints }\end{array}$ & $\begin{array}{l}\text { Exposure } \\
\text { concentration }\end{array}$ & Reference \\
\hline Tebuconazole & 0.75 & 22 & both & 10 & $\begin{array}{l}\text { Function of } \\
\text { time }\end{array}$ & $(32)$ \\
& & & & & $0.09 \mathrm{ppm}$ & $(33)$ \\
Diazinon (0.1ppm) & 0.4 & $20-22$ & both & 9 & $0.38 \mathrm{ppm}$ & $(33)$ \\
Diazinon (0.4ppm) & 0.4 & $20-22$ & both & 9 & $0.2 \mu \mathrm{g} / \mathrm{L}$ & $(30)$ \\
Endosulfan alpha & 0.27 & 22 & n.d. & 8 & $0.1 \mu \mathrm{g} / \mathrm{L}$ & $(30)$ \\
Endosulfan beta & 0.27 & 22 & n.d. & 8 & $97.5 \mu \mathrm{g} / \mathrm{L}$ & $(56)$ \\
Bisphenol A & n.d. & 27 & both & 8 & Function of & $(31)$ \\
Ethinyl-estradiol & 0.25 & 26 & male & 8 & time &
\end{tabular}

Table 3. Comparison between measured $\log \lambda_{b w}$, and the values predicted by Equations 1 and 4 for different chemicals.

\begin{tabular}{lllllll}
\hline $\mathrm{N}$ & Chemical & $\log K_{\text {ow }}$ & \multicolumn{3}{c}{$\log \lambda_{b w}$} & \multicolumn{2}{c}{$\mathrm{Nb}^{*}$} \\
& & & Eq. 1 & Eq. 4 & Obs. & \\
\hline 1 & 1,2-dichloroethane & 1.48 & 0.33 & 0.34 & 0.38 & 1 \\
2 & 1,1',2-trichloroethane & 1.89 & 0.65 & 0.60 & 0.56 & 1 \\
3 & Benzene & 2.13 & 0.84 & 0.74 & 0.98 & 1 \\
4 & 1,1',2,2'-tetrachloroethane & 2.39 & 1.04 & 0.91 & $0.71-1.25$ & 4 \\
5 & pentachloroethane & 3.22 & 1.69 & 1.42 & $1.05-1.79$ & 15 \\
6 & Hexachloroethane & 4.14 & 2.40 & 1.99 & $1.75-2.34$ & 4 \\
7 & 2,2',5,5'-tetrachlorobiphenyl & 6.09 & 3.91 & 3.20 & $3.00-4.18$ & 11 \\
8 & 2,2',4,4',5,5'-hexachlorobiphenyl & 6.80 & 4.47 & 3.64 & $3.96-4.85$ & 11 \\
9 & 2,2',3,3',5,5',6,6'-octachlorobiphenyl & 7.15 & 4.74 & 3.86 & $4.30-5.18$ & 11 \\
10 & decachlorobiphenyl & 8.26 & 5.60 & 4.55 & $4.43-5.48$ & 11 \\
11 & Chlorpyrifos & 4.96 & 3.04 & 2.50 & 3.24 & 1 \\
12 & Methoxychlor & 5.08 & 3.13 & 2.58 & 3.72 & 1 \\
13 & Nonylphenol & 5.76 & 3.66 & 3.00 & 4.38 & 1 \\
14 & Pyrene & 4.88 & 2.97 & 2.45 & 3.69 & 1 \\
\hline
\end{tabular}

* indicates the number of measurements, which may have been performed on different species. 


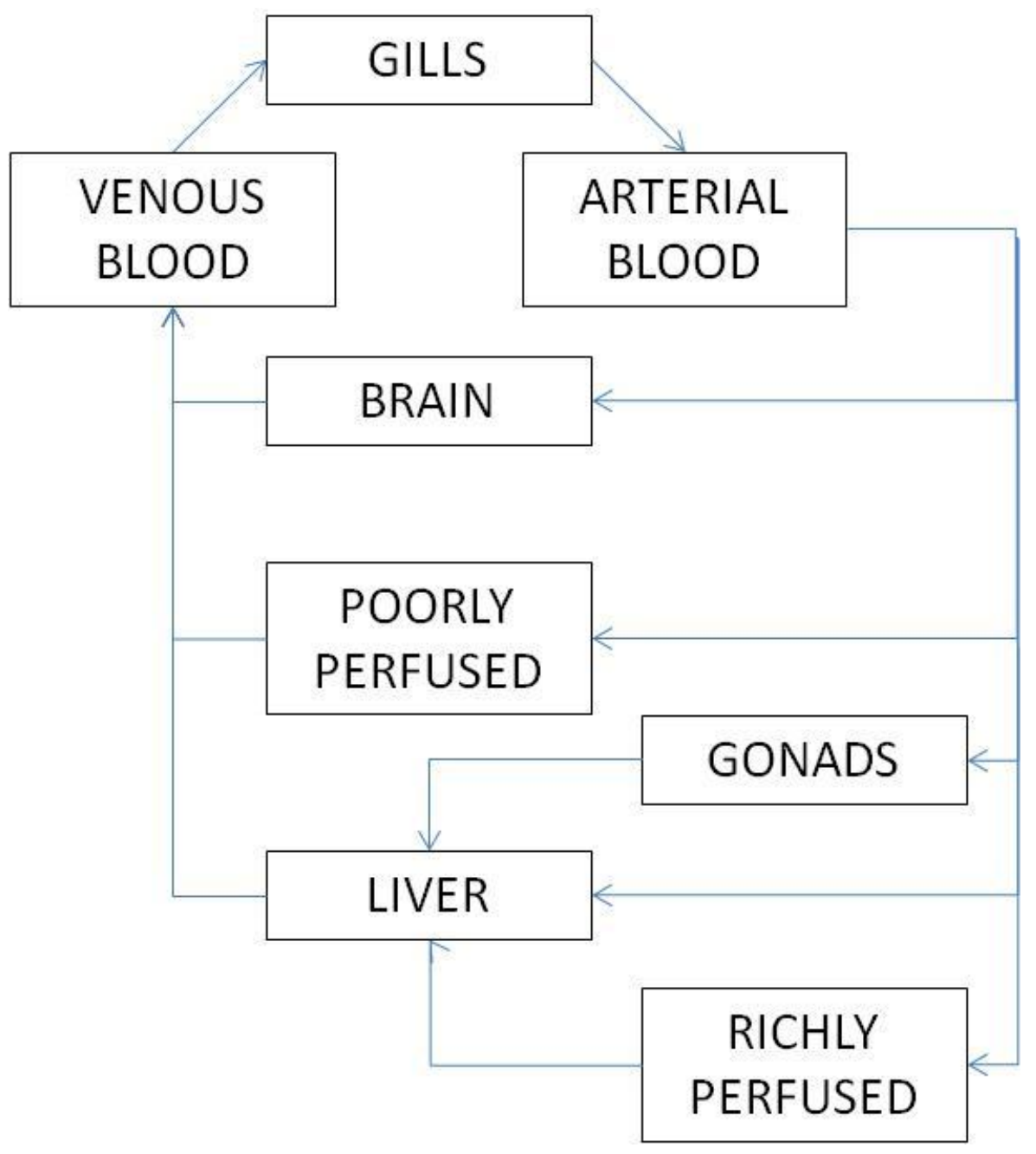

Figure 1. Schematic description of our zebrafish PBPK model. 


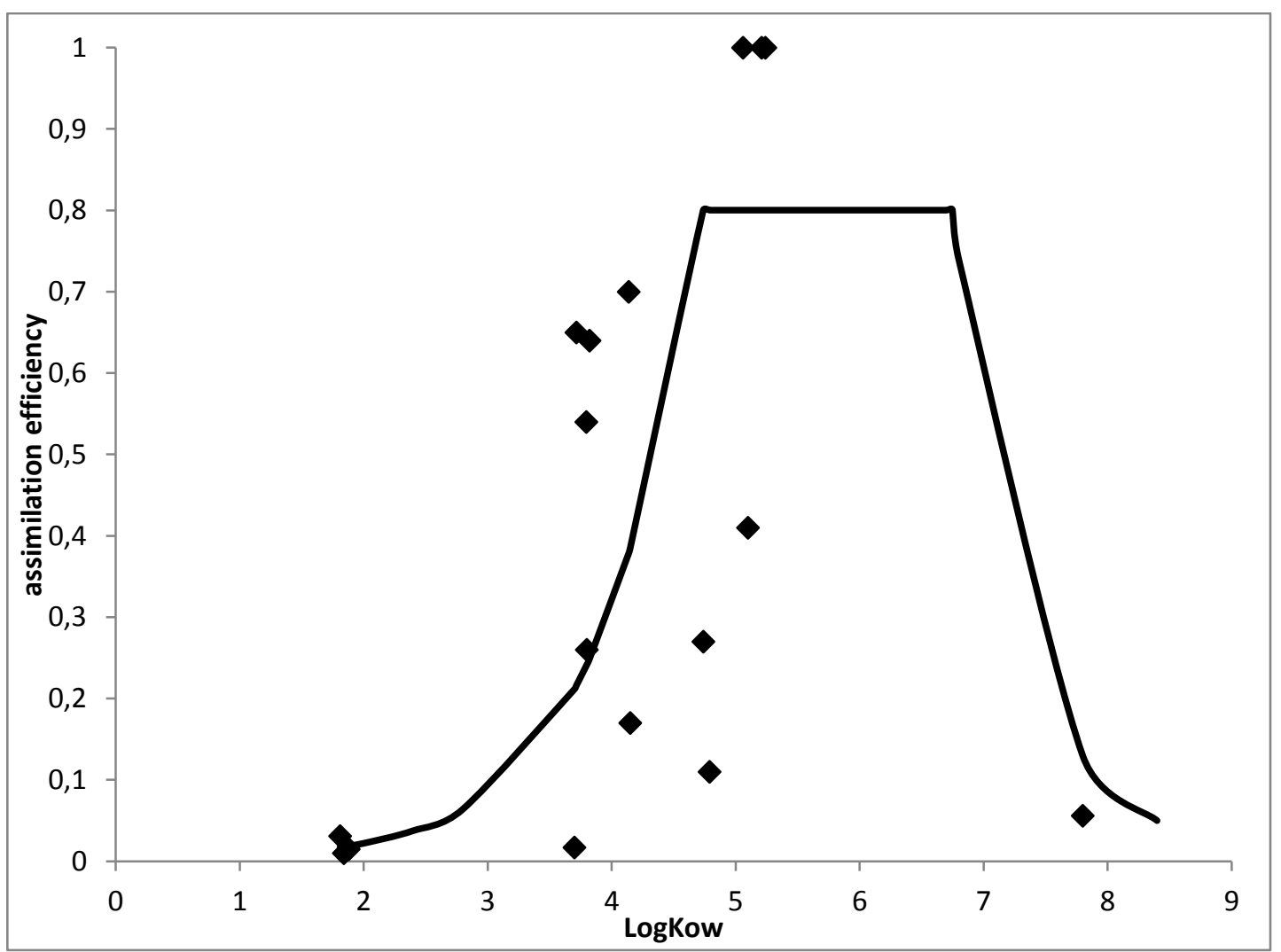

Figure 2. Relationship between gill assimilation efficiency and $\log K_{o w}$ (diamonds: measured data scaled for temperature and body weight, line: model as described in Barber $^{18}$ ).

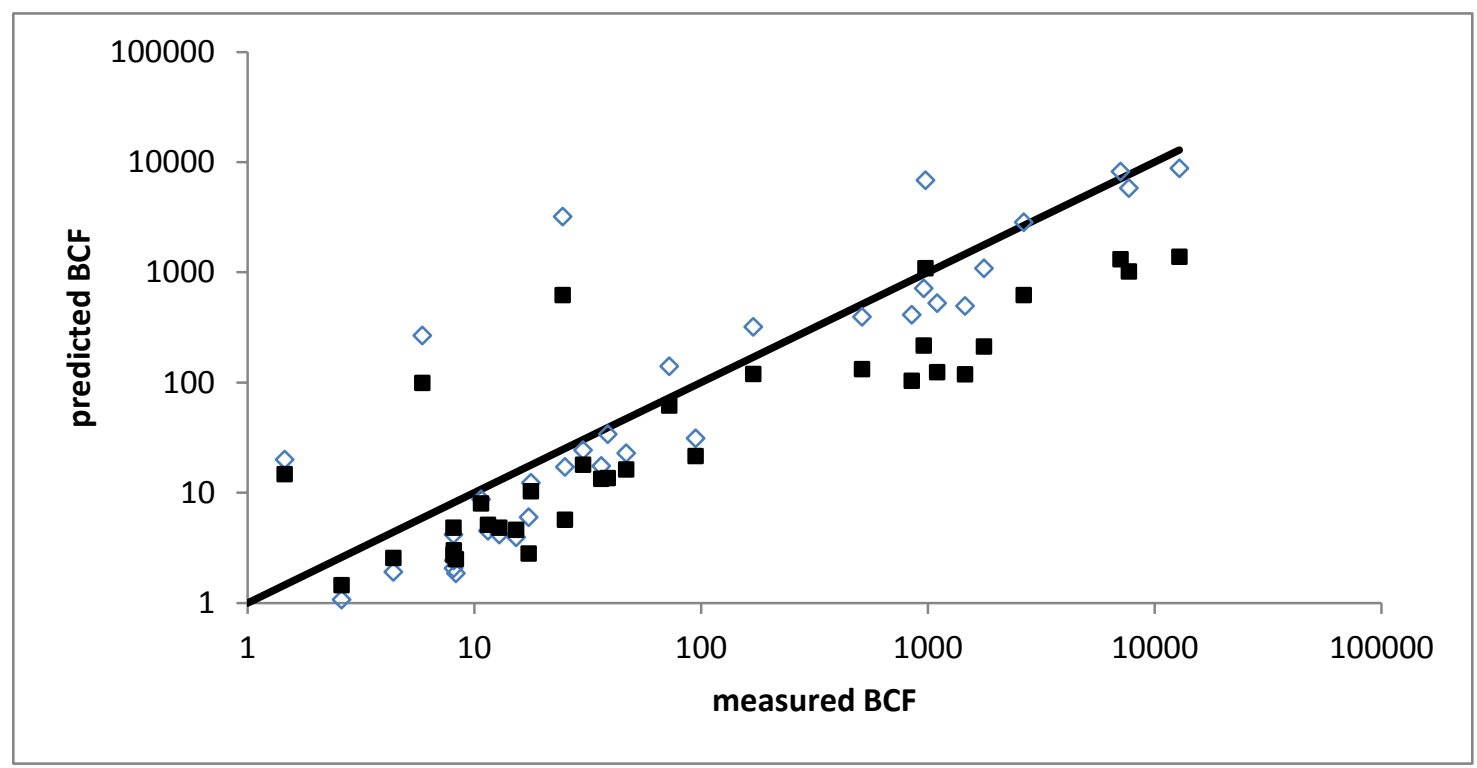

Figure 3. Comparison between measured $\mathrm{BCF}$ and the predictions from the model by Bertelsen et al. (plain squares) and by Nichols et al. (diamonds). 

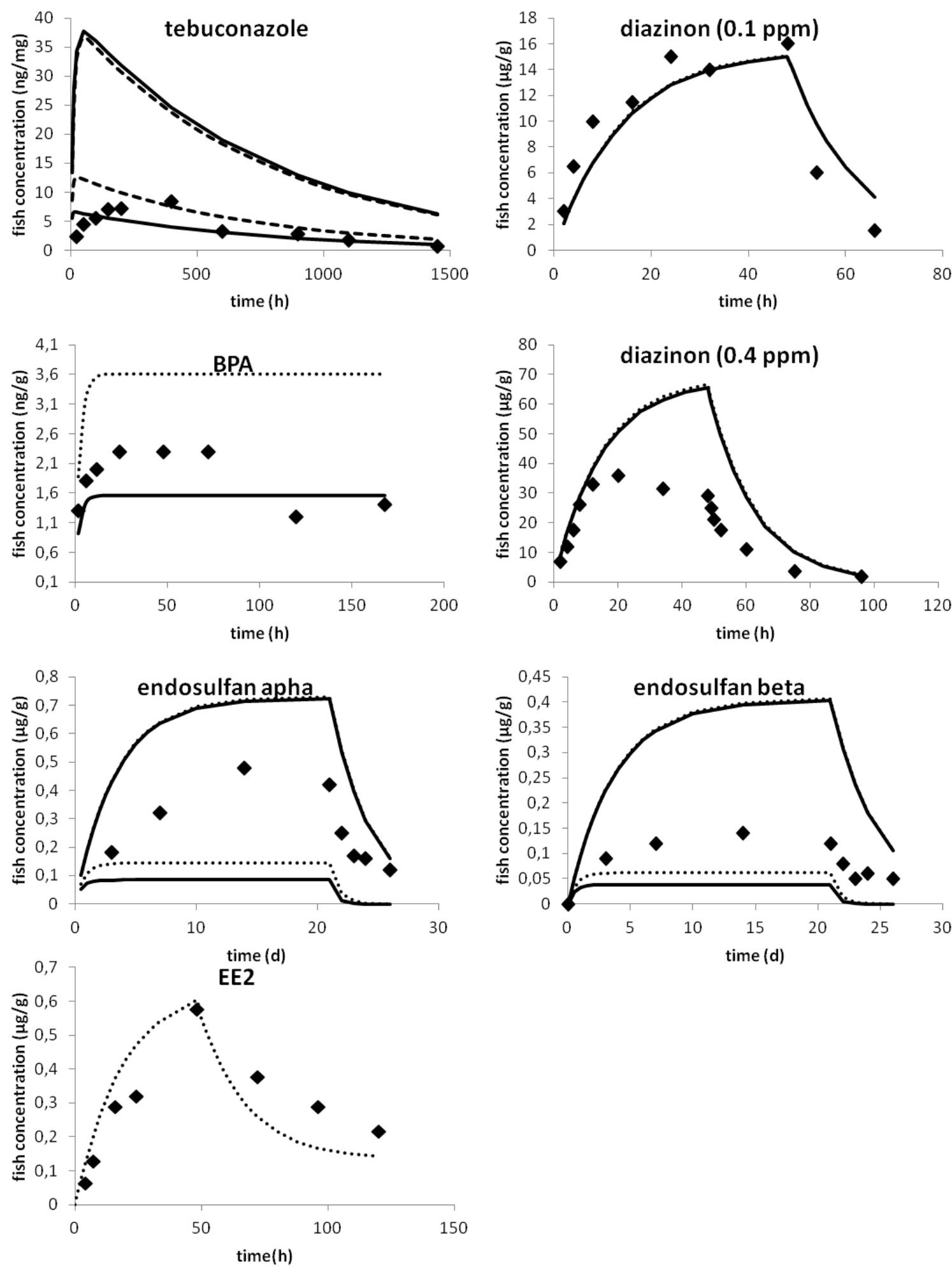

Figure 4. Comparison between measured toxicokinetics data (diamonds) and the predictions with our PBPK model (plain lines: males; dashed lines: females) for six chemicals. When two lines are proposed, the one with the highest values corresponds to an absence of metabolism. 


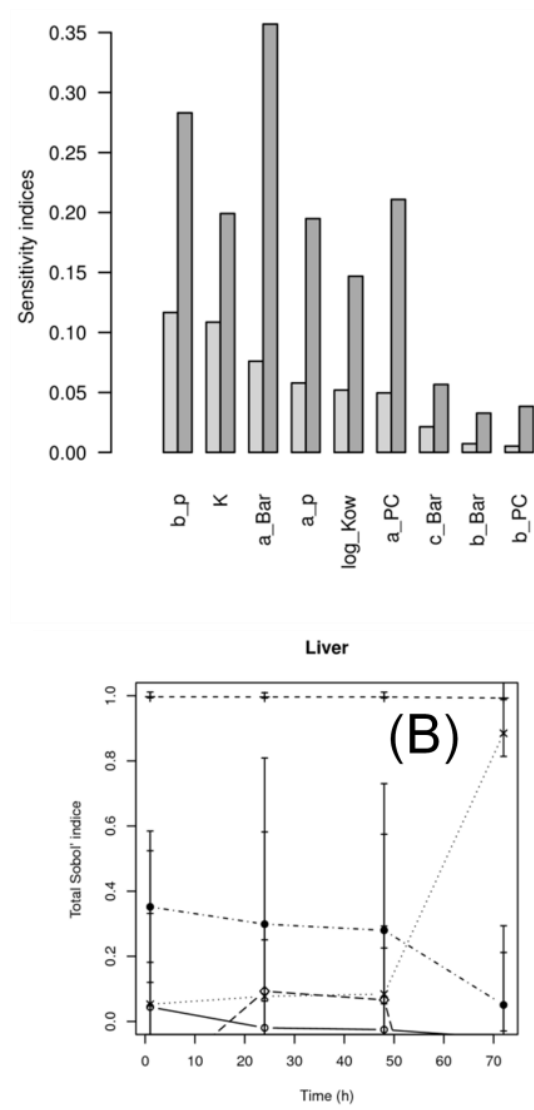

(A)

Figure 5. (A) Mean of the sensitivity indices at the different times and in the different compartments (Light grey: first order Sobol sensitivity index; dark grey: total Sobol sensitivity index). Parameters were ordered according to the first order Sobol sensitivity index. (B, C, D) Total sobol index for respectively liver, gonads and brain concentrations as a function of time. 


\section{SUPPORTING INFORMATION}

A generic physiologically-based toxicokinetics model for the zebrafish Danio rerio

Alexandre R.R. Péry", James Devillers, Céline Brochot, Enrico Mombelli, Olivier Palluel, Benjamin Piccini, François Brion, Rémy Beaudouin

* Corresponding author

Phone: +33 344556126

e-mail: alexandre.pery@ineris.fr 


\section{Supplementary material}

S1. Symbols and equations of the PBPK model. The generic index $i$ can be replaced by $b, l, g$ $p p$ and $r p$ referring respectively to blood, liver, gonads, poorly perfused tissues and richly perfused tissues.

\begin{tabular}{|c|c|c|}
\hline Parameter & Units & Description \\
\hline$B W$ & $\mathrm{mg}$ & Body weight \\
\hline $\mathrm{Ci}$ & $\mu \mathrm{mol} / \mathrm{L}$ & Concentration in organ $i$ \\
\hline$C_{\text {water }}$ & $\mu \mathrm{mol} / \mathrm{L}$ & Concentration in the water \\
\hline$V i$ & $\mathrm{~L}$ & Volume of organ $i$ \\
\hline$F i$ & $\mu \mathrm{L} / \mathrm{min}$ & Fraction of blood flow in organ $i$ \\
\hline frac_i & - & Fraction of blood flow in organ $i$ \\
\hline$s c \_i$ & - & Fraction of body weight in organ $i$ \\
\hline water_i & - & Water content of organ $i$ \\
\hline lipids_i & - & Lipid content of organ $i$ \\
\hline $\log K_{o w}$ & - & logarithm of the 1-octanol/water partition coefficient \\
\hline$P C_{i}$ & - & Partition coefficient between organ $i$ and blood \\
\hline$a \_T$ & ${ }^{\circ} \mathrm{C}^{-1}$ & Correction factor for temperature \\
\hline$\overline{K m}$ & $\mu \mathrm{mol} / \mathrm{L}$ & Michaelis constant \\
\hline Vmax & See S5 & Maximum velocity \\
\hline$a \_C O$ & $\mu \mathrm{L} / \mathrm{min}$ & Cardiac output \\
\hline$\alpha$ & - & Assimilation efficiency \\
\hline$a \_v r$ & $\mathrm{~mL} / \mathrm{min}$ & Ventilation rate \\
\hline$\lambda_{b w}$ & - & Blood:water partition coefficient \\
\hline$T$ & ${ }^{\circ} \mathrm{C}$ & Temperature \\
\hline$a \_p$ & - & $\begin{array}{l}\text { First coefficient in the equation relating assimilation efficiency } \\
\text { and } \log K_{o w}\end{array}$ \\
\hline$b \_p$ & - & $\begin{array}{l}\text { Second coefficient in the equation relating assimilation } \\
\text { efficiency and } \log K_{o w}\end{array}$ \\
\hline$a \_P C$ & - & $\begin{array}{l}\text { First coefficient in the equation relating partition between blood } \\
\text { and water and } \log K_{o w}\end{array}$ \\
\hline$b \_P C$ & - & $\begin{array}{l}\text { Second coefficient in the equation relating partition between } \\
\text { blood and water and } \log K_{o w}\end{array}$ \\
\hline a_Bar & - & $\begin{array}{l}\text { First coefficient in the equation relating partition between tissue } \\
\text { and blood and } \log K_{o w}\end{array}$ \\
\hline b_Bar & - & $\begin{array}{l}\text { Second coefficient in the equation relating partition between } \\
\text { tissue and blood and } \log K_{o w}\end{array}$ \\
\hline c_Bar & - & $\begin{array}{l}\text { Third coefficient in the equation relating partition between } \\
\text { tissue and blood and } \log K_{o w}\end{array}$ \\
\hline
\end{tabular}

The chemicals are distributed in brain, gonads, poorly perfused tissues, and richly perfused tissues through blood flows with the following equation: 
For the liver, accounting for fish blood circulation and possible metabolism, we have the following equation:

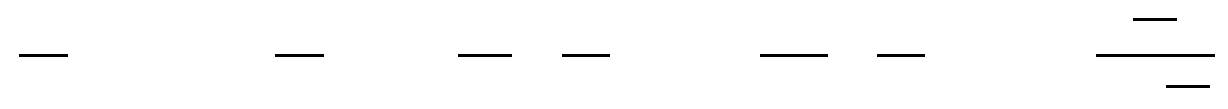

The equation for arterial blood is the following:

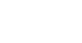

The equation for venous blood is:

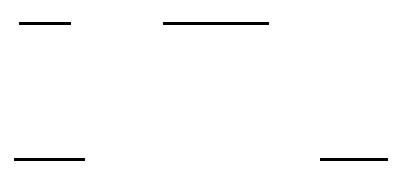

In the case of EE2, we also had to account for the disappearance of the substance in the exposure solution due to accumulation in the fish (and the appearance of the substance in the exposure solution during depuration). The equation was as follows:

with a volume of the solution, $V_{s}$, of $800 \mathrm{~mL}(31)$, considering only substance accumulation and elimination in fish to drive concentration in the solution. 
S2. Wet and dried weights of Danio rerio adult males and females from the INERIS laboratory culture. All weights are in $\mathrm{mg}$. Each line correspond to one organism.

\begin{tabular}{|l|l|l|l|l|l|l|l|l|l|l|}
\hline Sex & $\begin{array}{l}\text { Total } \\
\text { weight }\end{array}$ & $\begin{array}{l}\text { Length } \\
(\mathrm{mm})\end{array}$ & $\begin{array}{l}\text { Brain } \\
\text { wet } \\
\text { weight }\end{array}$ & $\begin{array}{l}\text { Brain } \\
\text { dried } \\
\text { weight }\end{array}$ & $\begin{array}{l}\text { Liver } \\
\text { wet } \\
\text { weight }\end{array}$ & $\begin{array}{l}\text { Liver } \\
\text { dried } \\
\text { weight }\end{array}$ & $\begin{array}{l}\text { Gonads } \\
\text { wet } \\
\text { weight }\end{array}$ & $\begin{array}{l}\text { Gonads } \\
\text { dried } \\
\text { weight }\end{array}$ & $\begin{array}{l}\text { Carcass } \\
\text { wet } \\
\text { weight }\end{array}$ & $\begin{array}{l}\text { Carcass } \\
\text { dried } \\
\text { weight }\end{array}$ \\
\hline M & 599 & 41 & 8.7 & 2.2 & 6.5 & 2.1 & 11.3 & 5.8 & 542.3 & 158.8 \\
\hline M & 703 & 43 & 7.9 & 2.1 & 9.1 & 3.3 & 10.3 & 4.3 & 652.3 & 196.1 \\
\hline M & 561 & 40 & 9.5 & 2.7 & 4.4 & 1.3 & 12.4 & 5.9 & 504.9 & 161 \\
\hline M & 584 & 41 & 9.6 & 2.2 & 3.7 & 1.3 & 8.8 & 4.1 & 533.8 & 171.5 \\
\hline M & 497 & 39 & 7.9 & 1.8 & 3.1 & 1 & 7.8 & 3.8 & 454.8 & 143.3 \\
\hline M & 616 & 41 & 11 & 3 & 4.9 & 1.7 & 12.3 & 6.8 & 555.6 & 186.7 \\
\hline M & 769 & 44 & 9.2 & 2.1 & 2.2 & 0.7 & 11.1 & 4.9 & 706.2 & 229.1 \\
\hline M & 561 & 39 & 9.2 & 2.2 & 3.9 & 1.7 & 11.5 & 5.6 & 509.3 & 157 \\
\hline M & 596 & 42 & 9.1 & 2.2 & 4.8 & 1.7 & 11.1 & 5.8 & 548.8 & 178.6 \\
\hline M & 690 & 42 & 9.1 & 2.1 & 6.5 & 2.4 & 13.1 & 5.9 & 631.7 & 217 \\
\hline F & 774 & 39 & 7 & 1.3 & 17.4 & 5.2 & 138.7 & 37.7 & 550.8 & 185.5 \\
\hline F & 845 & 45 & 6.9 & 1.7 & 23.2 & 6 & 152.7 & 56.7 & 629.9 & 202.3 \\
\hline F & 735 & 38 & 5.8 & 1.4 & 12.2 & 4.3 & 143.7 & 53.2 & 548.2 & 219.7 \\
\hline F & 1,220 & 45 & 7.4 & 1.7 & 27.9 & 9.1 & 141.1 & 38.6 & 968.2 & 335.8 \\
\hline F & 1,170 & 47 & 7.4 & 2.1 & 20.8 & 7 & 265.2 & 97.7 & 837.6 & 306.1 \\
\hline F & 1,495 & 49 & 8.3 & 2.1 & 31.4 & 9.1 & 386.3 & 143.4 & $1,022.3$ & 352.4 \\
\hline F & 1,025 & 41 & 7.9 & 1.8 & 28.6 & 9.2 & 232.5 & 85.2 & 694.4 & 273.6 \\
\hline F & 778 & 38 & 5.8 & 1.8 & 11.3 & 3.8 & 113.4 & 43.1 & 513.3 & 189.1 \\
\hline F & 1,695 & 51 & 9.7 & 2.6 & 27 & 8.2 & 519.7 & 201 & 1,038 & 347.4 \\
\hline F & 980 & 43 & 6.7 & 1.6 & 21.7 & 6 & 157.2 & 43.5 & 737.1 & 249.9 \\
\hline
\end{tabular}

S3. Relationship between percentage of gonads weight in total wet weight and total weight of Danio rerio adult females based on data from this study, from IRSN colleagues and from Örn et al. ${ }^{16}$.

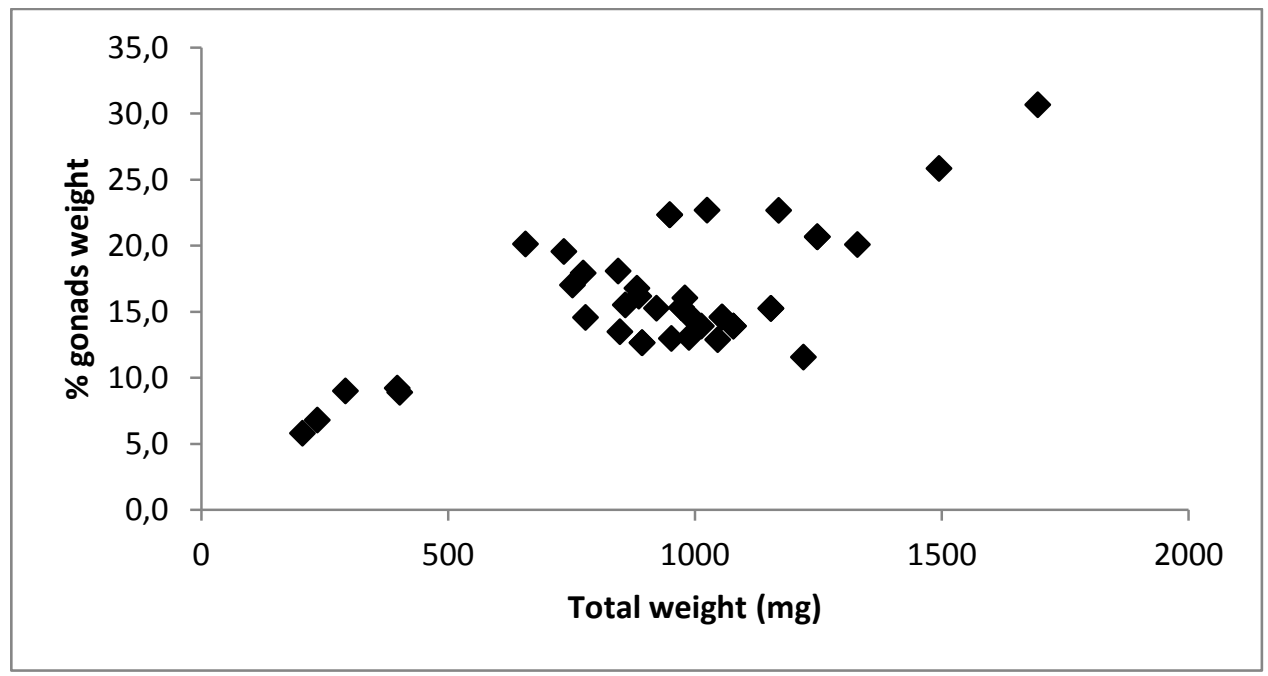


S4. Metabolism data used in our study.

\begin{tabular}{|c|c|c|c|c|}
\hline Substance & Vmax & $\begin{array}{l}\mathrm{Km} \\
(\mu \mathrm{M})\end{array}$ & Type of cell & Reference \\
\hline Tebuconazole & $1.05 \mu \mathrm{M} / \mathrm{min} / \mathrm{mg}$ protein & 13.53 & $\begin{array}{l}\text { Rat liver } \\
\text { microsomes }\end{array}$ & $(44)$ \\
\hline Diazinon & $0.031 \mu \mathrm{M} / \mathrm{min} / \mathrm{mg}$ protein & 11 & $\begin{array}{l}\text { Zebrafish S-13 } \\
\text { liver cell fraction }\end{array}$ & $(33)$ \\
\hline Endosulfan alpha & $1.48 \mathrm{pmol} / \mathrm{min} / \mathrm{pmol} \mathrm{P} 450$ & 7.34 & $\begin{array}{l}\text { Human liver } \\
\text { microsomes }\end{array}$ & $(45)$ \\
\hline Endosulfan beta & $4.40 \mathrm{pmol} / \mathrm{min} / \mathrm{pmol} \mathrm{P} 450$ & 6.37 & $\begin{array}{l}\text { Human liver } \\
\text { microsomes }\end{array}$ & $(45)$ \\
\hline
\end{tabular}

S5. Comparison between the relationships between predicted (line) and measured (diamonds) assimilation efficiency without (upper figure) or with (lower figure) corrections for temperature and weight.
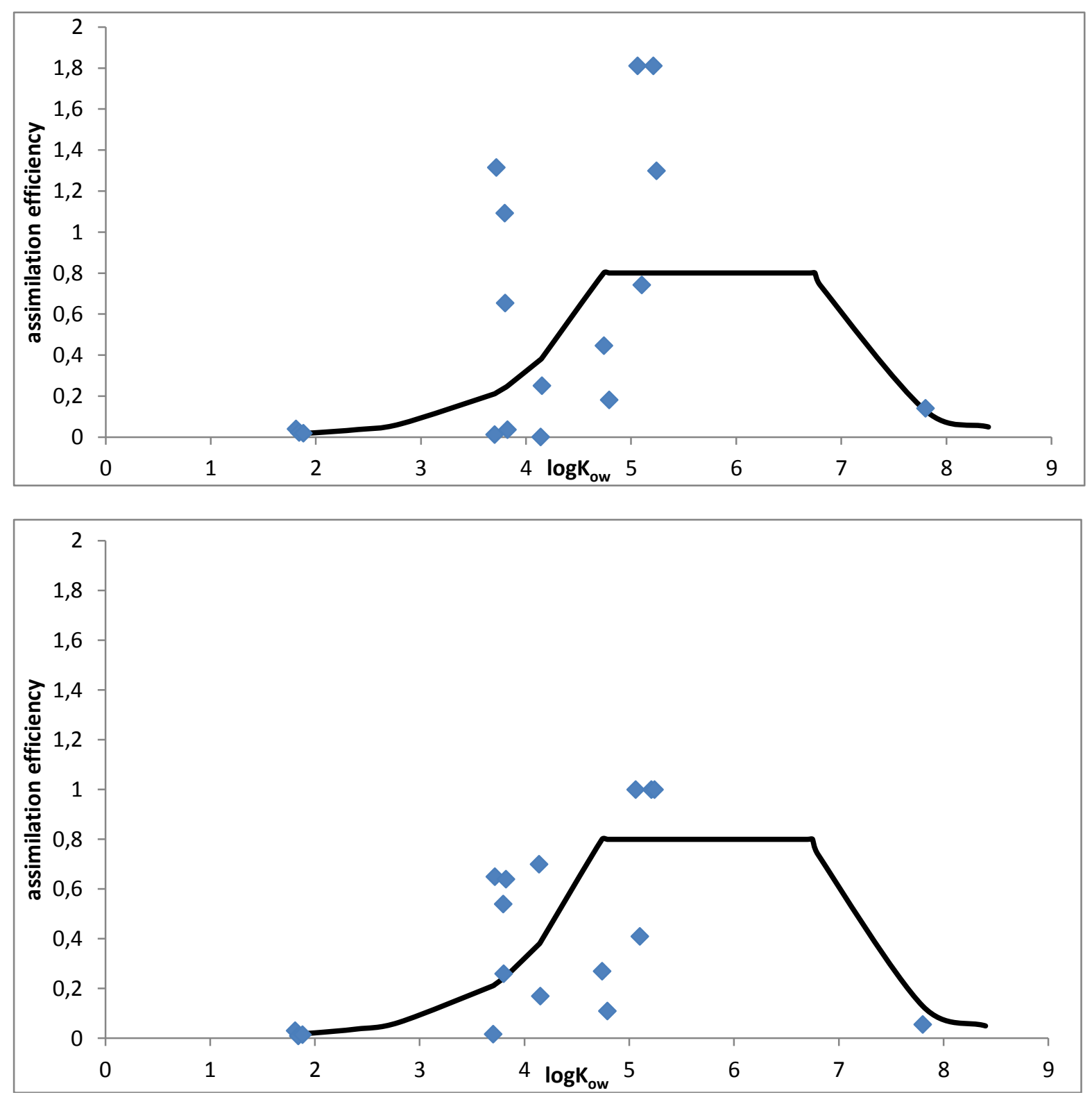
S6. Comparison between measured $\mathrm{BCF}$ and the predictions from equations 2 (plain squares), 3 (diamonds) and the best regression model in Bintein et al. ${ }^{53}$ (plain circles).

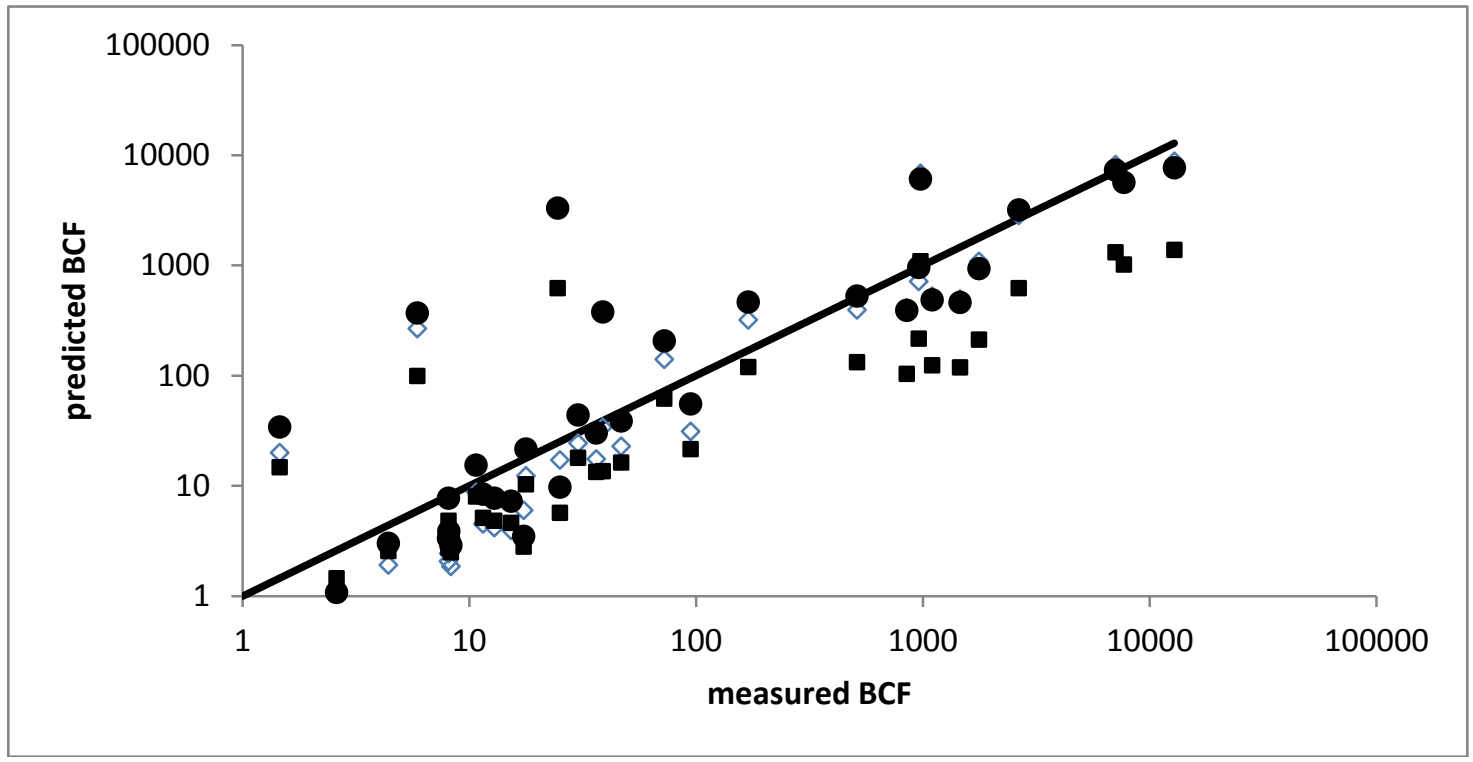

S7. Comparison between predicted and measured data for the toxicokinetic studies.

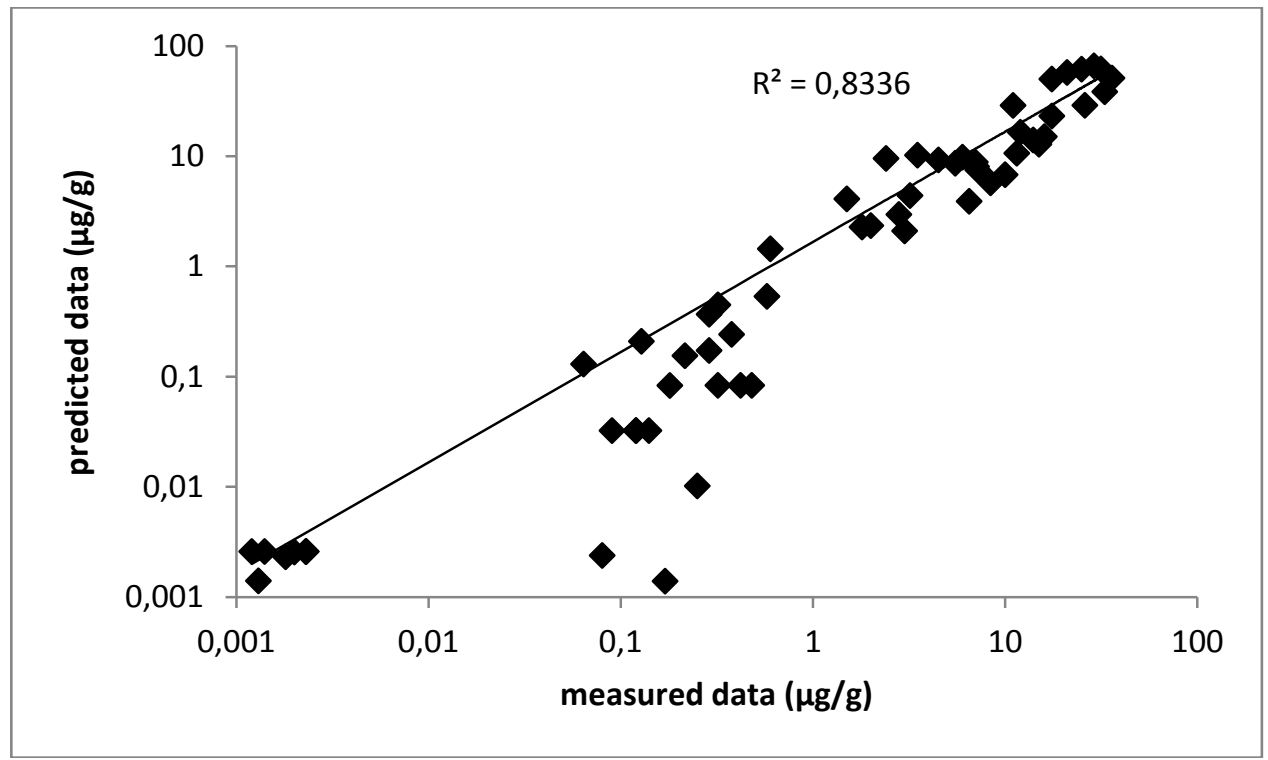


S8. Additional details of the sensitivity analysis.

The parameters we considered in the sensitivity analysis were those relative to the physiology of zebrafish (body weight, volumes and blood flow rates, lipid and water contents, basal ventilation rate $\left(a \_v r\right)$, basal cardiac output $\left.\left(a_{-} C O\right)\right)$, temperature, $\log K_{\text {ow }}$, the correction factor for temperature $\left(a_{-} T\right)$ and, finally, the parameters of the following equations for assimilation efficiency and partition coefficients:

With no prior information available on the parameters, the input parameter values for the sensitivity analysis were sampled from a uniform distribution. For metabolism, we used a clearance rate $K$ (defined as the ratio between $V_{\max }$ and $K_{m}$ ) defined by a uniform distribution between 0 (no metabolism) and 10,000 (high metabolism rate) to cover a large range of values from no to high metabolism. For $\log K_{o w}$, experts in the predictions of this parameters consider a confidence interval of $[-0.5,0.5]$ around the median value. For all the other parameters, lower and upper limits of the uniform distributions were defined as $\pm 20 \%$ around prior value. The prior mean values for all the parameters in the sensitivity analysis study were the values of the diazinon PBPK model for males. A first sensitivity analysis was performed with all parameters, a second one with all parameters except those of the equations for assimilation efficiency and partition coefficients to assess the influence of test conditions (organism physiological state, temperature) when assessing kinetics of a given chemical with data from one study. 
S9. Results of the sensitivity analysis (total (dark grey) and first order (light grey) Sobol indices) per organ and time of measurement. In this sensitivity analysis, we considered all the parameters of our model.
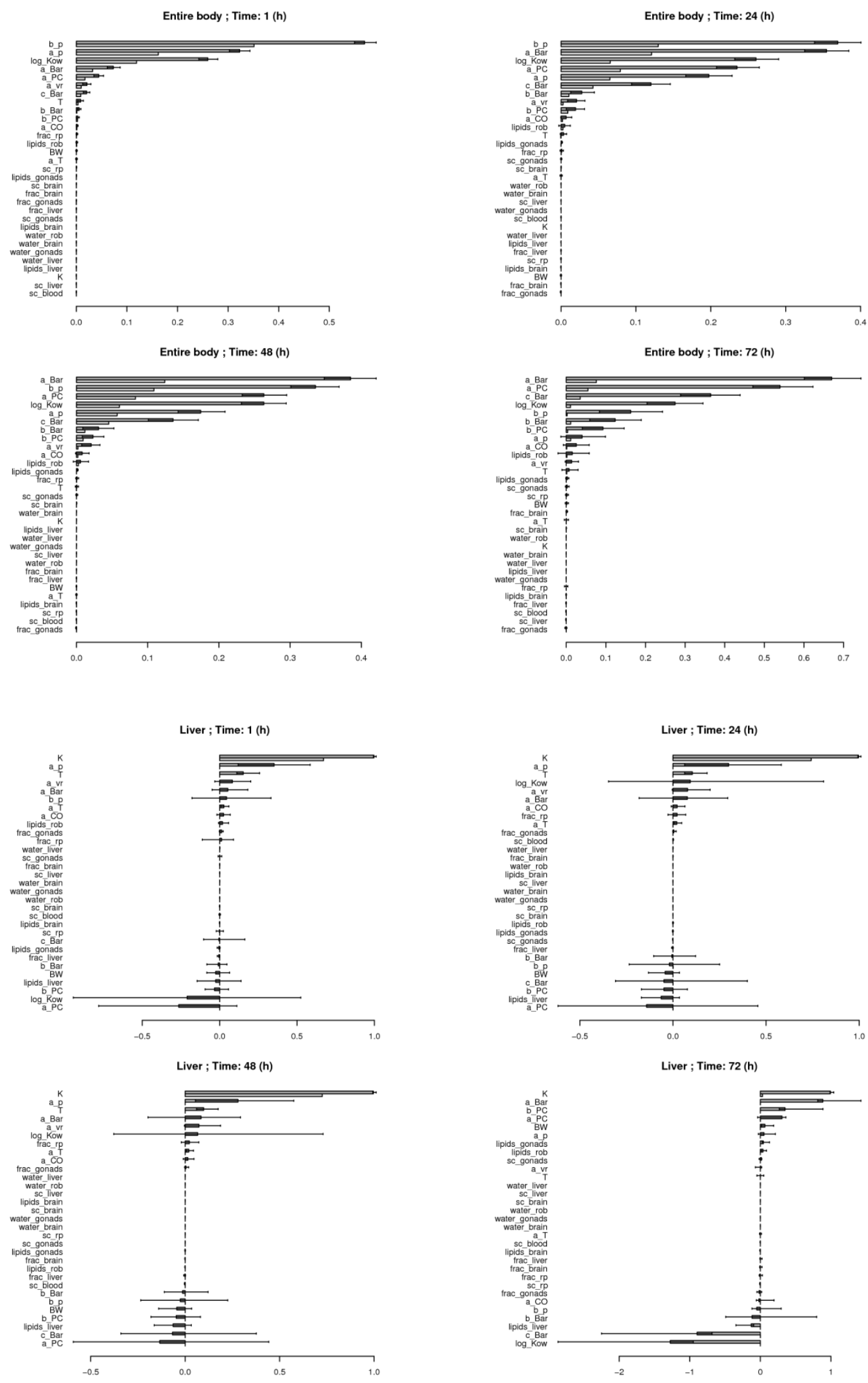

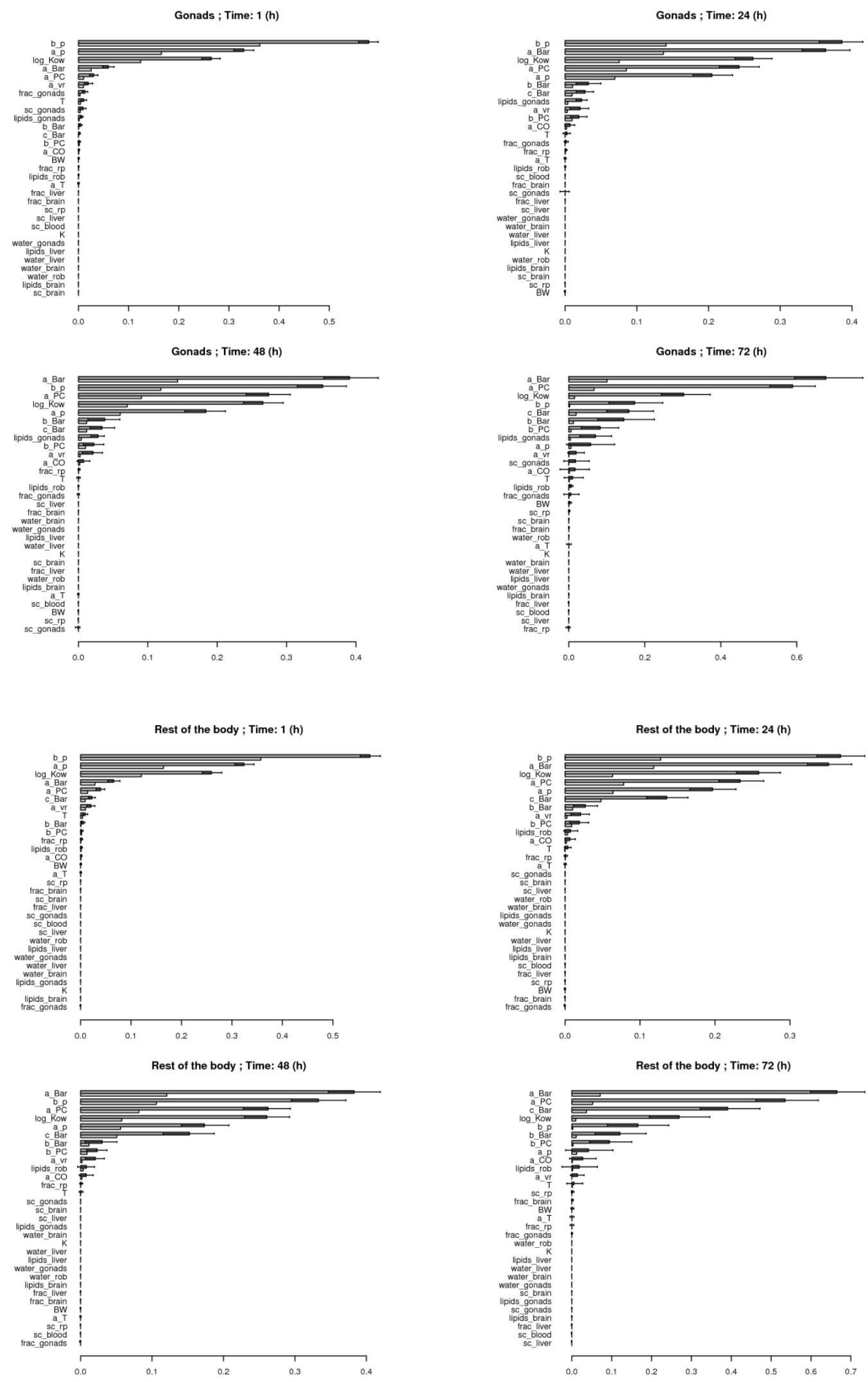

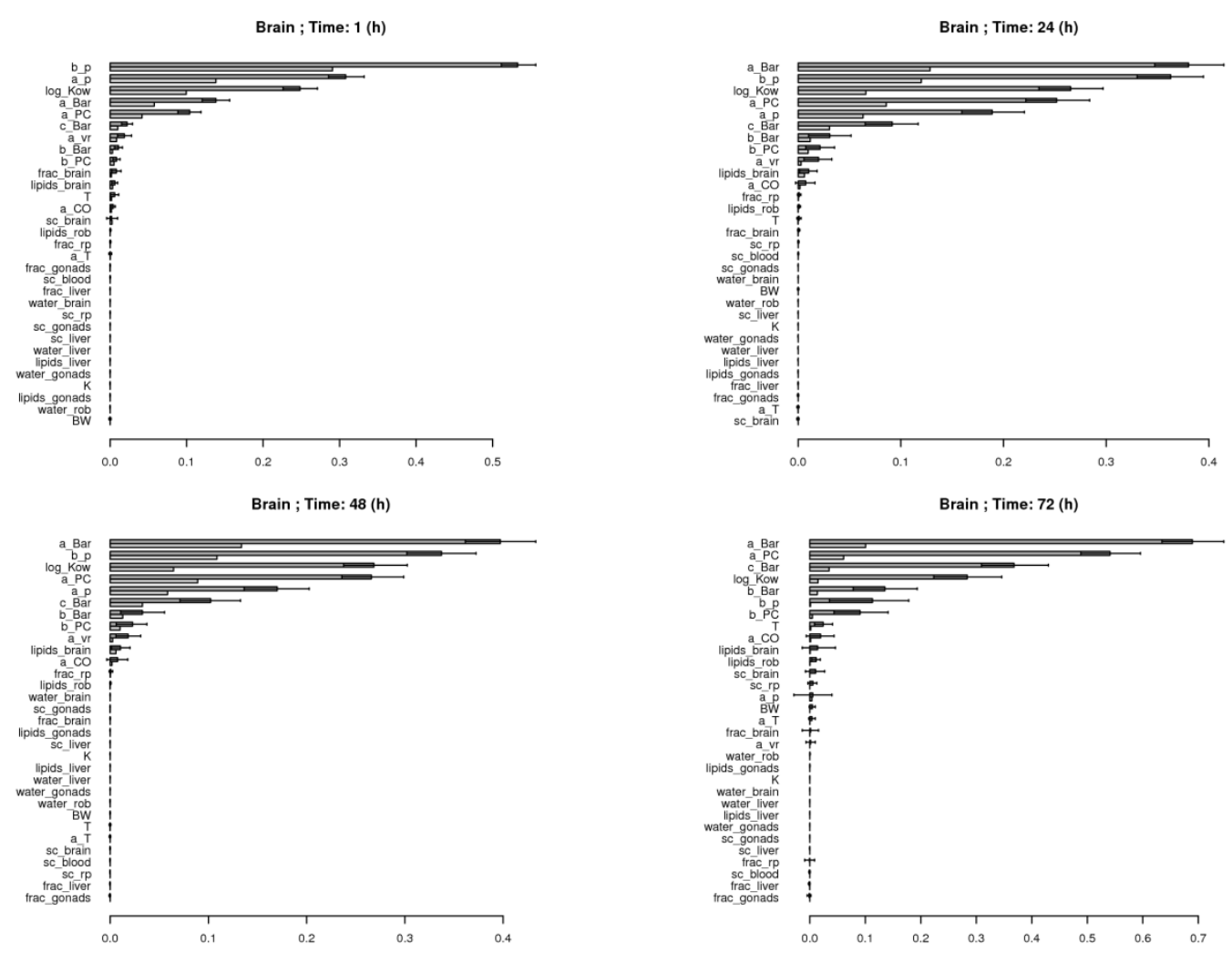
S10. (A) Mean of the sensitivity indices at the different times and in the different compartments (Light grey: first order Sobol sensitivity index; dark grey: total Sobol sensitivity index). Parameters were ordered according to the first order Sobol sensitivity index. (B, C, D) Total sobol index for respectively liver, gonads and brain concentrations as a function of time. In this sensitivity analysis, we considered all the parameters of our model except those of the submodels for partition coefficients and assimilation efficiency.
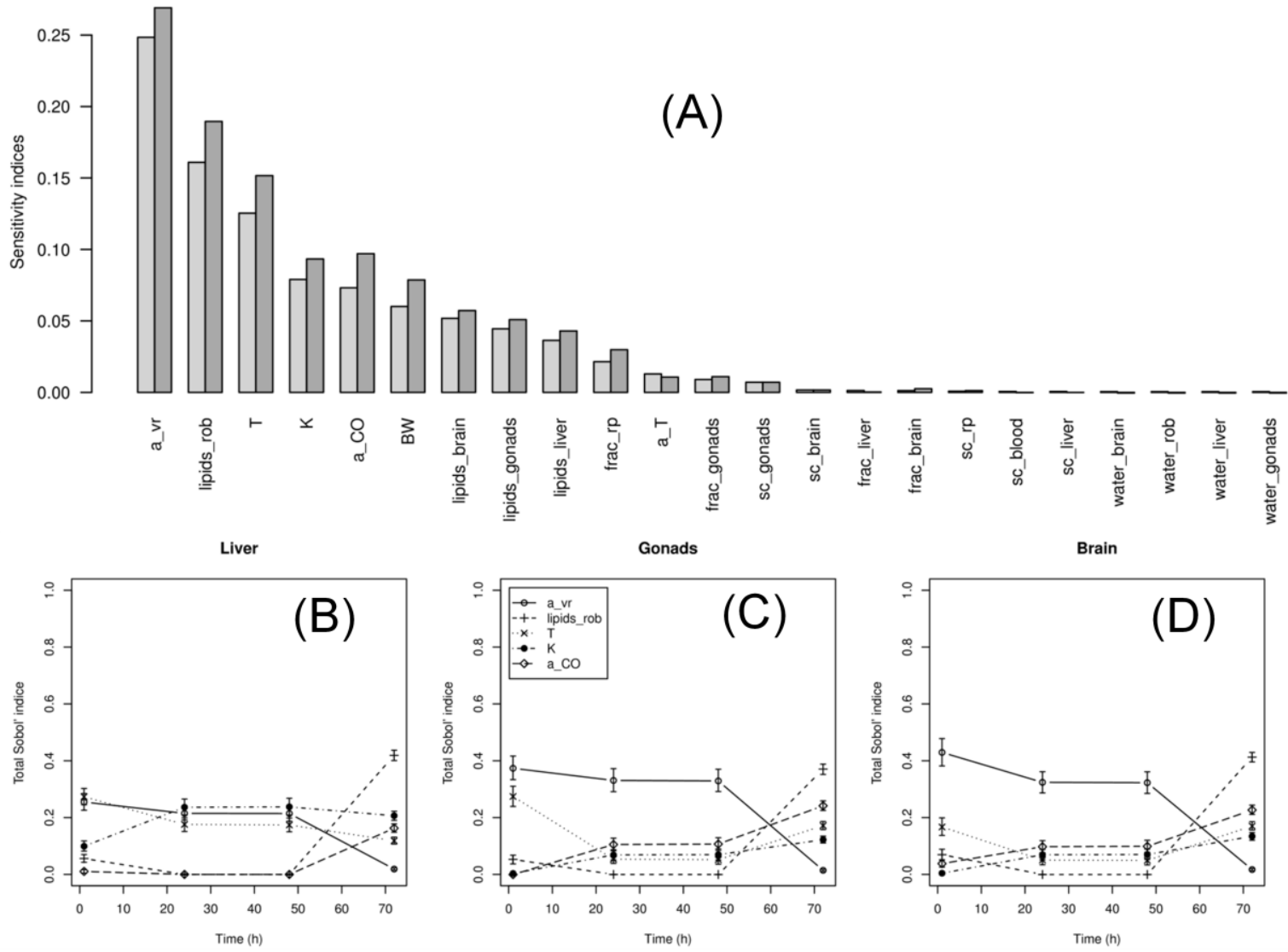
S11. Results of the sensitivity analysis (total (dark grey) and first order (light grey) Sobol indices) per organ and time of measurement. In this sensitivity analysis, we considered all the parameters of our model except those of the submodels for partition coefficients and assimilation efficiency.
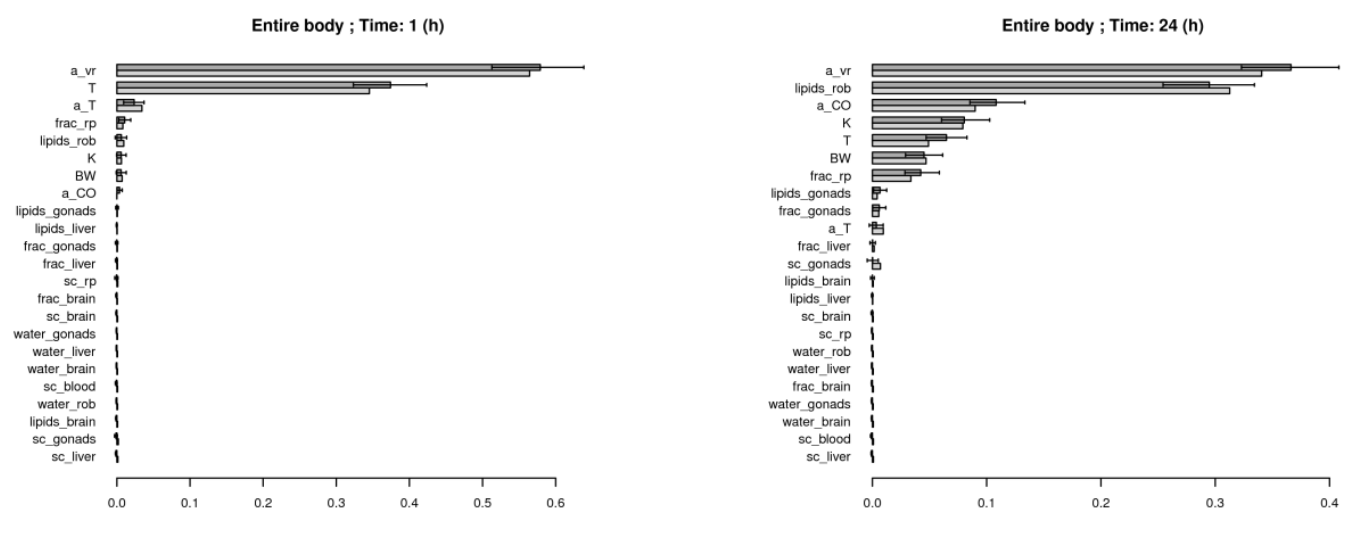

Entire body ; Time: 48 (h)

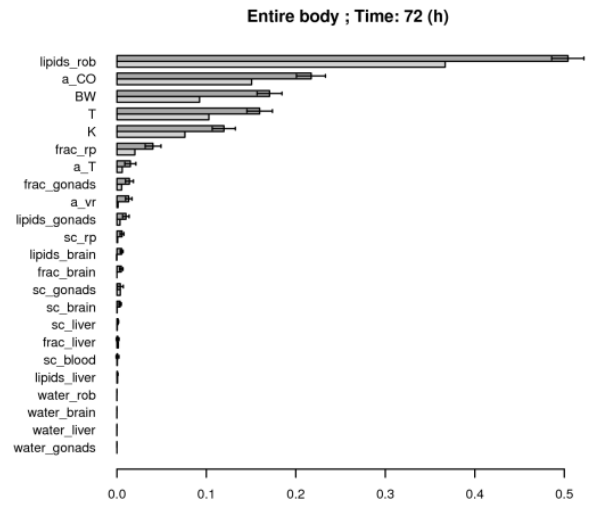


Liver ; Time: 1 (h)
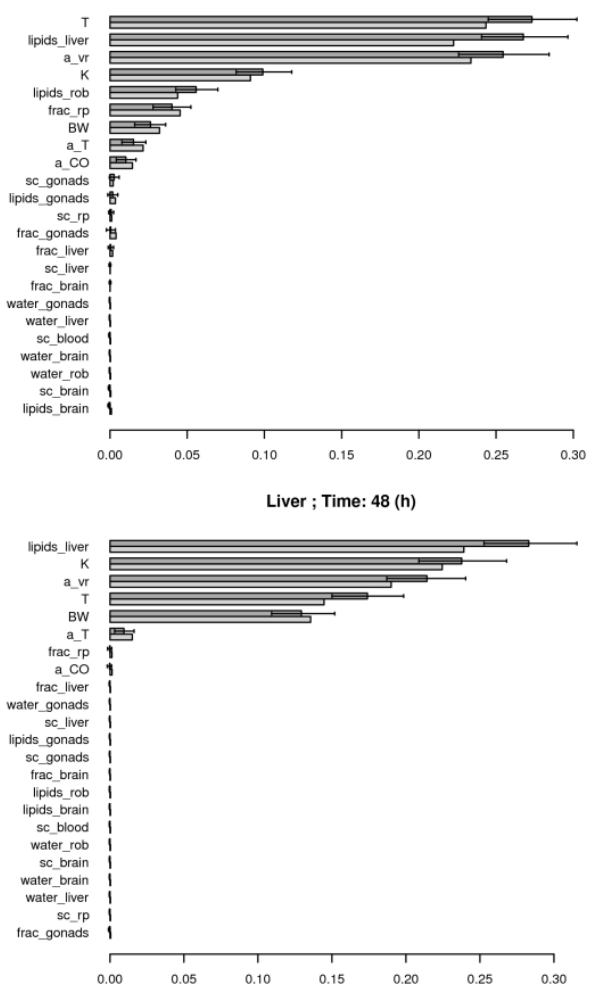

Rest of the body ; Time: 1 (h)
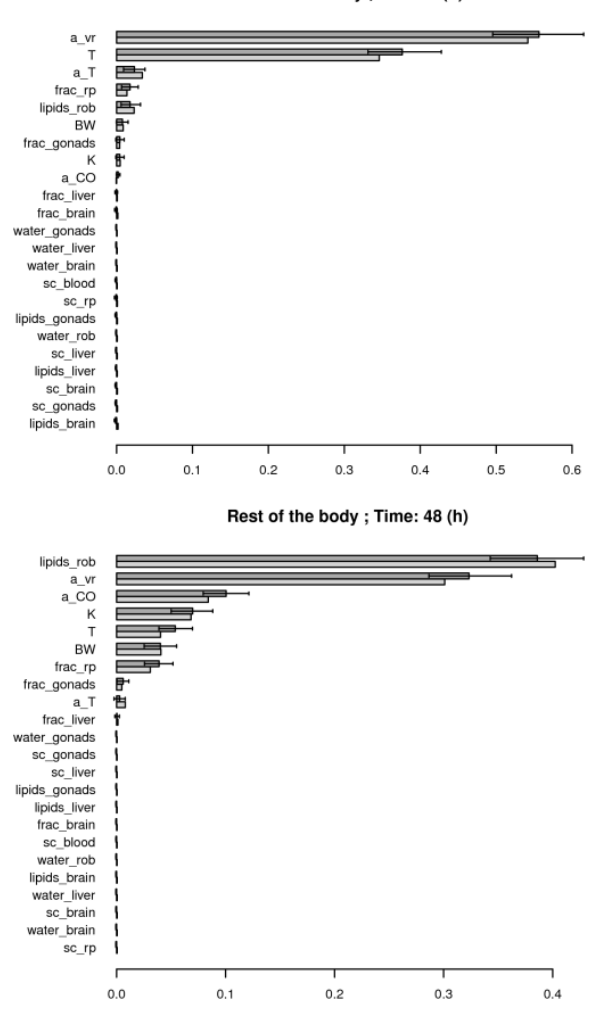

Liver ; Time: 24 (h)
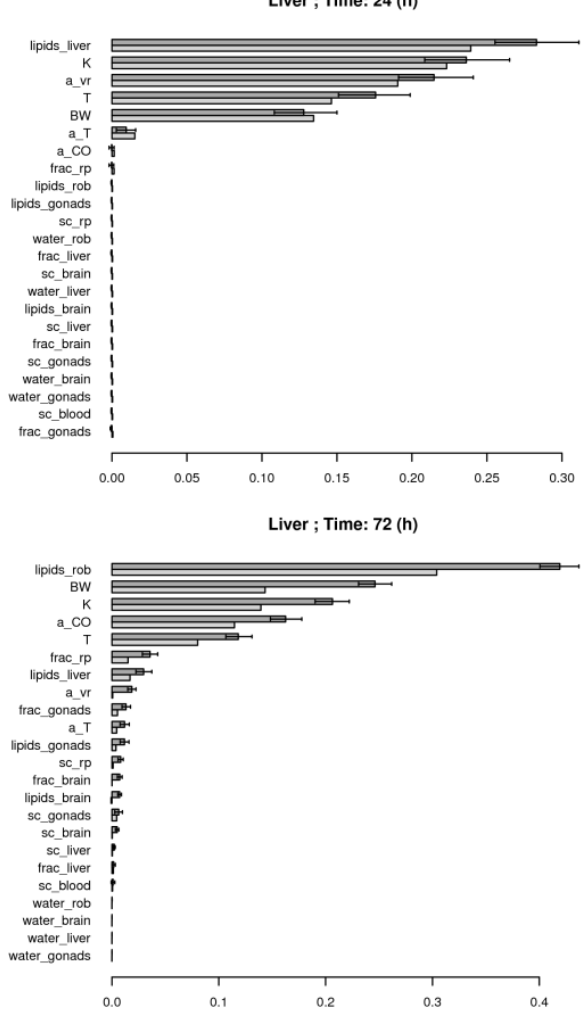

Rest of the body ; Time: 24 (h)
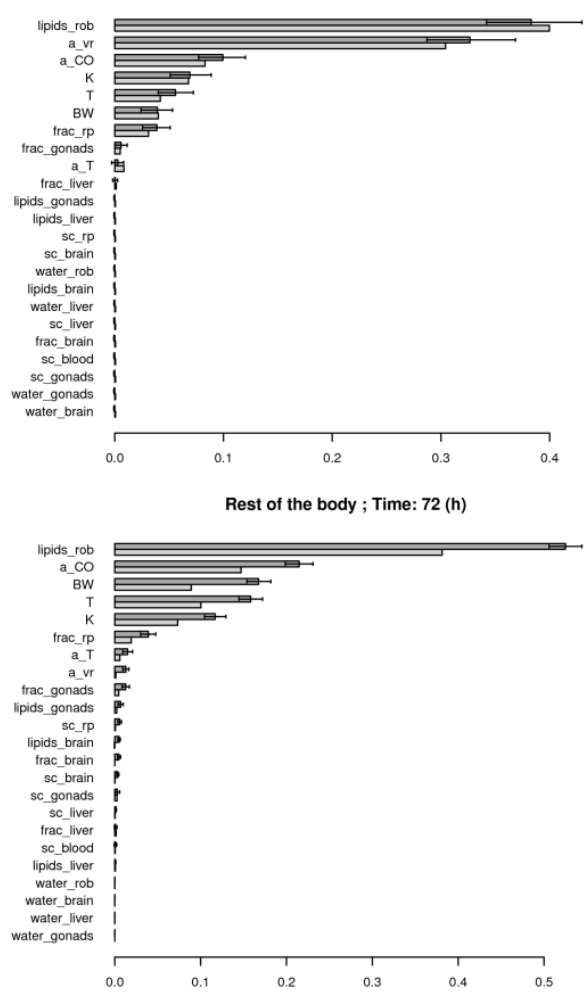
Gonads ; Time: 1 (h)
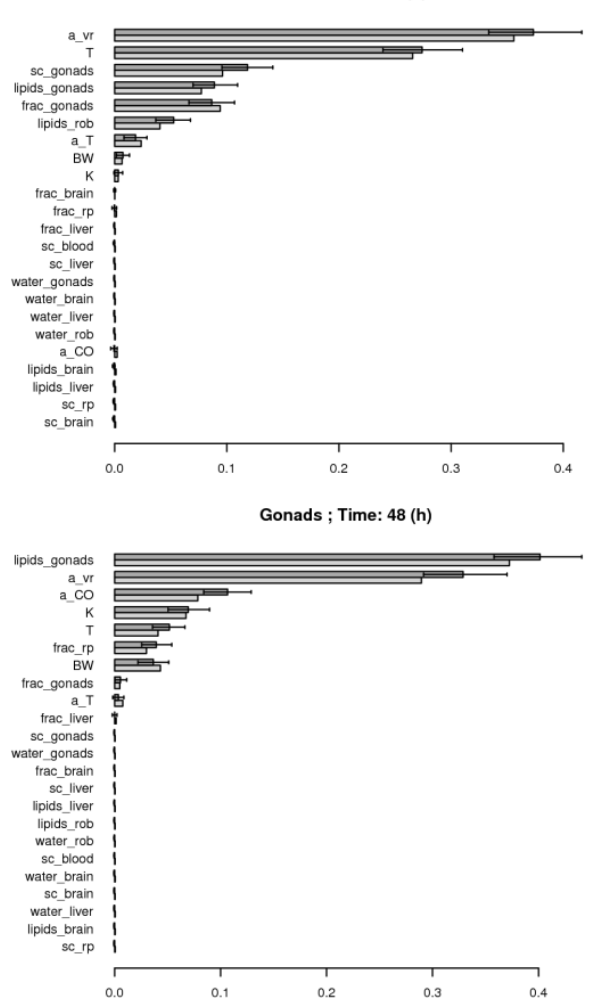

Brain ; Time: 1 (h)
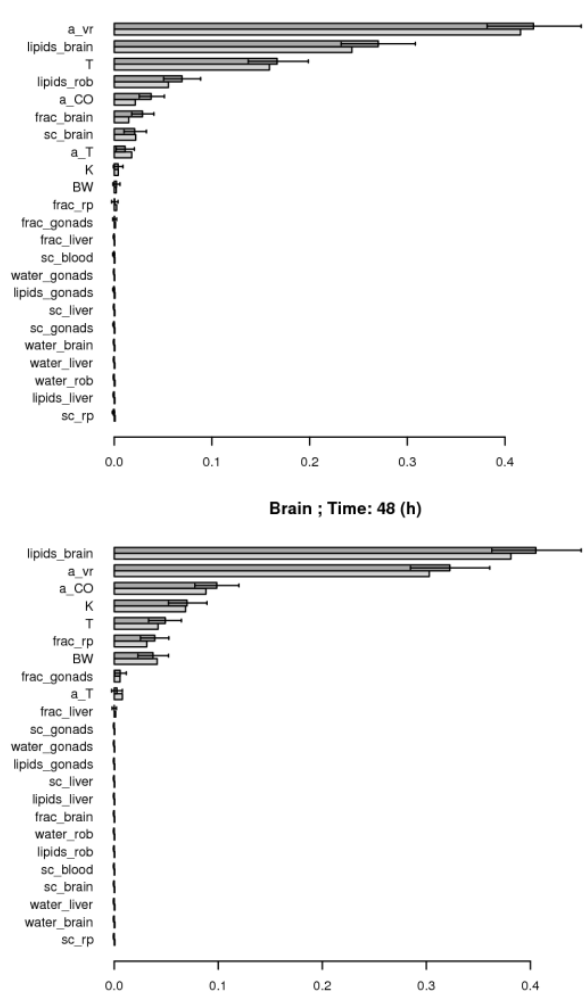

Gonads ; Time: 24 (h)

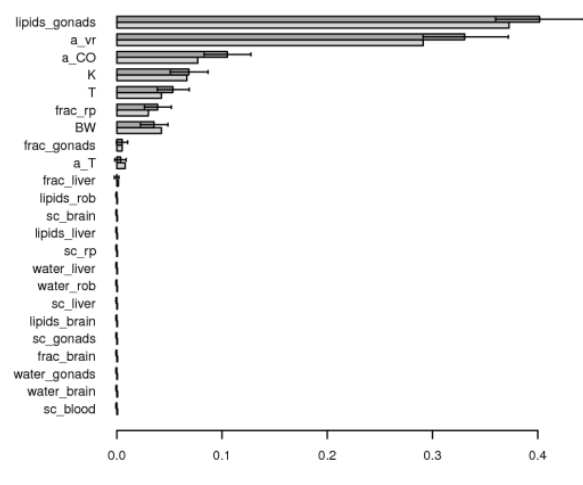

Gonads ; Time: 72 (h)

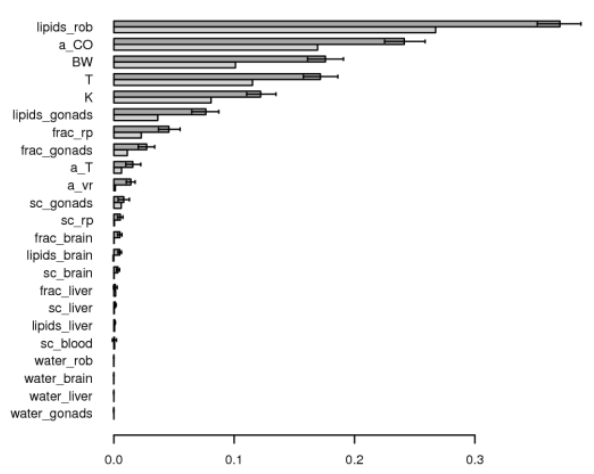

Brain ; Time: 24 (h)

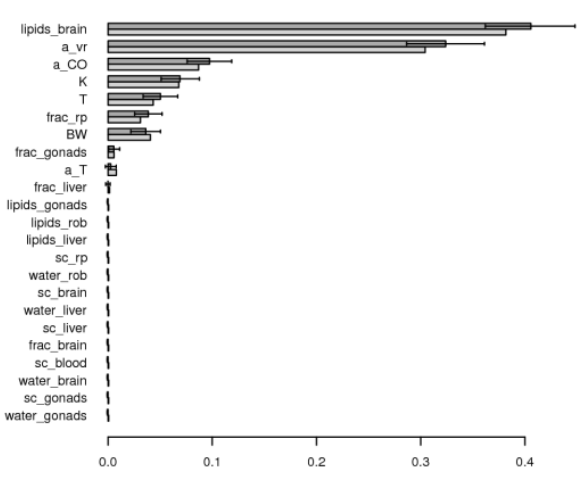

Brain ; Time: 72 (h)

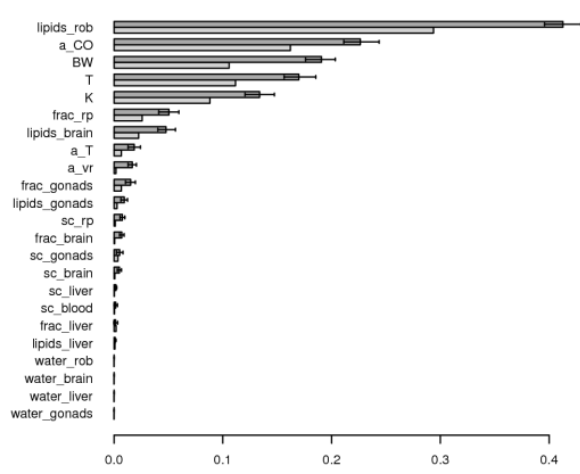

